\title{
The persistent place at Lubrza: a small paradise for hunter-gatherers? Multi-disciplinary studies of Late Palaeolithic environment and human activity in the Łagów lake district (western Poland)
}

\author{
Iwona Sobkowiak-Tabaka ${ }^{1}$ (D) Krystyna Milecka ${ }^{2}$. Lucy Kubiak-Martens ${ }^{3} \cdot$ Dominik Pawłowski $^{4}$. \\ Aldona Kurzawska ${ }^{5}$ - Beata Janczak-Kostecka ${ }^{2} \cdot$ Robert Kostecki $^{2}$ - Iwona Hildebrandt-Radke ${ }^{2}$ Karina Apolinarska $^{4}$. \\ Tomasz Goslar ${ }^{6,7}$
}

Received: 30 June 2021 / Accepted: 1 November 2021 / Published online: 2 December 2021

(c) The Author(s) 2021

\begin{abstract}
This paper summarises the results of multidisciplinary research, including pollen, plant macroremains, diatoms, Cladocera, molluscs and geochemistry from a ${ }^{14} \mathrm{C}$ dated core and geomorphological records, which reconstruct the palaeoenvironmental conditions faced by Late Palaeolithic hunter-gathers in western Poland. Particular attention was paid to evidence for both human activity and the degree to which Late Palaeolithic groups may have affected the local environment, as recorded by the biogenic sediments in lakes located close to their campsites. Vegetation first appears locally in the Oldest Dryas, and consisted of subarctic tundra vegetation. During the Bølling period the landscape was generally open, with dwarf shrubs and scattered patches of Juniperus and Hippophaë shrubs. Betula (tree birch) expanded locally in the area only in the later Allerød; during the second part of the Allerød period, Pinus and Populus joined birch as a sparse woodland developed. During the Younger Dryas, the landscape changed significantly in comparison to the preceding warm period, as result of cooling and drying of the climate. The presence of microscopic charcoal and charred herbaceous plant particles made it possible to detect human activity. These analyses allowed us to reconstruct fire events near the site during its occupation by Hamburg and Federmesser cultural groups. An increase in the proportion of biogenic elements such as $\mathrm{Na}, \mathrm{K}$ and $\mathrm{Mg}$ in the sediments indicate soil erosion, reflecting the activity of Hamburg groups. A relative increase in the frequency of Cladocera which favour eutrophic and turbid water was recorded in the period linked to Federmesser group activities. The intense use of this area was also indicated during the Younger Dryas.
\end{abstract}

Keywords Early human impact $\cdot$ Multi-proxy records $\cdot$ Hunter-gatherers $\cdot$ Human fire dynamics $\cdot$ Late Glacial

\section{Introduction}

Late Glacial hunter-gatherers of the North European Plain are widely seen as migrating groups whose mobility patterns were determined by annual animal migrations (Gordon

Communicated by K.-E. Behre.

Iwona Sobkowiak-Tabaka

iwosob@amu.edu.pl

1 Faculty of Archaeology, Adam Mickiewicz University, Uniwersytetu Poznańskiego 7, 61-612 Poznan, Poland

2 Institute of Geoecology and Geoinformation, Faculty of Geographical and Geological Sciences, Adam Mickiewicz University, B. Krygowskiego 10, 61-680 Poznan, Poland

3 Biological Archaeology \& Environmental Reconstruction, BIAX Consult, Symon Spiersweg 7 D2, 506 RZ Zaandam, The Netherlands
4 Institute of Geology, Faculty of Geographical and Geological Sciences, Adam Mickiewicz University, B. Krygowskiego 12, 61-680 Poznan, Poland

5 Institute of Archaeology and Ethnology, Polish Academy of Sciences, Rubież 46, 61-612 Poznan, Poland

6 Faculty of Physics, Adam Mickiewicz University, Umultowska 85, 61-614 Poznan, Poland

7 Poznan Radiocarbon Laboratory, Poznan Science and Technology Park, ul. Rubież 46, 61-612 Poznan, Poland 
1988; Binford 1991; Baales 1996, 1999). Even if alternative models are presented (Cziesla 2018), environmental conditions would still have played a significant role in the selection of camp sites and weapon types. Previous studies to identify the relationships between past human activities and their natural environment in western Poland indicate that hunter-gatherer groups preferred diversified areas, with varied elevations and sandy river or lake terraces which provided easy access to water (Kobusiewicz 1999; Jasiewicz and Sobkowiak-Tabaka 2015).

The Lubrza region in western Poland is unique for its sites which were repeatedly occupied by hunter-gatherers through different periods of the Late Glacial and the Holocene. As such, it had a concentration of human occupation, with four Late Palaeolithic sites discovered within ca. $1 \mathrm{~km}^{2}$ (Sobkowiak-Tabaka et al. 2018). Such regions, referred to as persistent places, are well known both in time and space (Schlanger 1992; Vanmontfort et al. 2010; Turner et al. 2013). Frequently visited by hunter-gatherers, these regions are ideal spots for studying human presence and activities in the past through natural archives, such as peat bog and lake deposits.

Previous results of archaeological and palaeoecological studies in the area (Sobkowiak-Tabaka et al. 2018) inspired a new multidisciplinary research project. In addition to pollen, macroremains and mollusc analyses, this project also included diatom and Cladocera analyses on the master organic sediment record retrieved from the Lubrza Late Glacial palaeolake. This combined study reconstructed the Late Glacial landscape and changing lake conditions in the area through time, including water nutrient status, water level and the accompanying physico-chemical parameters. Carbon and oxygen stable isotope analysis was also done on mollusc shells to further compliment the environmental and climatic reconstruction. All analyses used the samples from the master sediment sequence and were subsequently combined with radiocarbon dating.

This study also focused on identifying the evidence for the possible presence of Late Palaeolithic groups in the area and on indicating the intensity of this presence. Quantitative analysis was performed on microscopic charcoal and other charred plant particles in the analysed pollen samples to obtain information on the frequencies of fires during the period, which coincided with the accumulation of organic sediments in the Lubrza palaeolake. This is a potential indicator of human activity in the area and the results of the charred microscopic particle analysis may therefore help reconstruct the Palaeolithic landscape and its pattern of use.

Although the changes in Late Glacial vegetation patterns are usually associated with climate changes, our research investigated how quickly an ecological niche could be transformed or influenced by hunter-gatherers, and whether we can identify clear and significant traces of this process in lake archives using multi-proxy lines of evidence.

\section{Regional settings}

The archaeological sites in the Lubrza area are located $1.4 \mathrm{~km}$ north-east of Lubrza jezioro (Lubrza lake), in the Jordanów-Niesulice glacial channel (Fig. 1). The width of

Fig. 1 Map of the investigated area showing the Palaeolithic sites and the locations of the cores

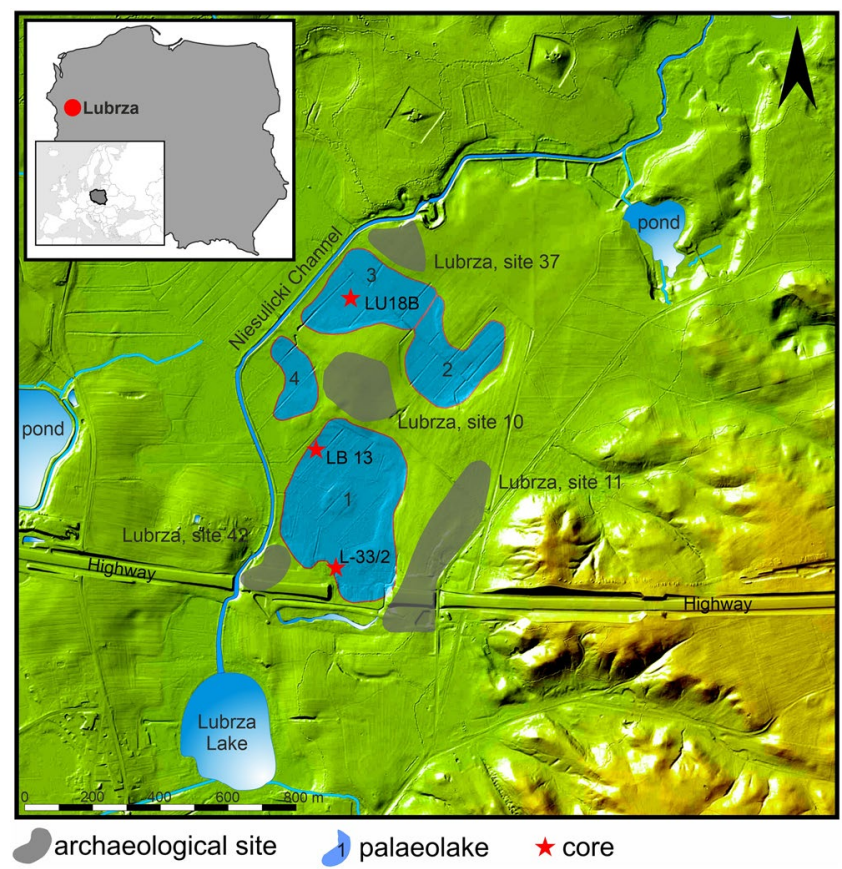


the glacial channel near the lake is over $1 \mathrm{~km}$, narrowing to about $0.1 \mathrm{~km}$ near the archaeological site.

The area was shaped as a result of erosion and accumulated meltwater associated with patches of dead ice blocks. As a result, a deep glacial channel with an uneven longitudinal section formed under the ice sheet (Żynda 1967; Chmal 2003). The shape of the bottom of the glacial channel is due to either the presence of ice blocks, either from the collapse of the top of the glacial tunnel or ice blocks tearing off and limiting the gap in the ice sheet. The spaces between the ice blocks filled with sediment deposited by constantly flowing meltwater in the channel; after filling the spaces between the ice blocks, the water then deposited sediments on the surfaces of the blocks. These layers could be several metres thick, and provided a certain level of insulation to further protect the dead ice blocks from rapid melting. Because of improving climatic conditions, the ice blocks eventually melted and formed lakes in addition to numerous accumulation landforms, islands and sandy peninsulas, which were oriented parallel and perpendicular to the main direction of the glacial channel. Today, evidence for these formation processes persists in sandy banks raised several metres above the level of the peat plain (Ratajczak-Szczerba 2014).

Campsites were located around the lakes, now filled with biogenic sediments. Analysis indicates that the sediments in this part of the glacial channel are very varied. The maximum recognized sediment depth was $9.50-10 \mathrm{~m}$, occasionally reaching as deep as $14.80 \mathrm{~m}$ in the hollows of fossil basins. Four such fossil basins were identified from geological borings (Sobkowiak-Tabaka et al. 2018).

In total, three biogenic sediment cores were taken (Fig. 1). The first two cores are associated with palaeolake 1, along the north (LB 13 and LB 2013) and south banks (L-33/2) (between sites 42 and 1, and 10). The final core (LU 18B) was taken near the centre of basin 3 (between sites 10 and 37). It is rather curious that we obtained different chronological records for the formation of palaeolakes 1 and 3 based on the analyses of these cores. In the southern part of palaeolake 1, the biogenic accumulation began in the pre-Allerød period (Bølling?); in the northern part of palaeolake 1, deposition took place during the Allerød (Sobkowiak-Tabaka et al. 2018). Palaeolake 3 started to develop in the Oldest Dryas and included the start of gyttja organic mud accumulation, which starts $9 \mathrm{~m}$ below the modern surface (Fig. 2a). The slopes along the southern lake shore are steep, while those along the eastern and northern slopes are gentle. The fossil basin is filled by detritus gyttja with molluscs, clayey and calcareous gyttja, grey or olive in colour (Fig. 2b). The basal peat, which is $5-25 \mathrm{~cm}$ thick and slightly to strongly decomposed, occurs in the southern part of the basin slope (Fig. 2c). Sedge moss peat deposits, which are midway decomposed and reach a maximum thickness of $2 \mathrm{~m}$ with a brown sandy layer at the top, cover the lake sediments (Ratajczak-Szczerba 2014).

\section{Archaeological overview}

There is a long history of archaeological research on the Late Palaeolithic and Mesolithic sites at Lubrza, with a great deal of interest in the reconstruction of local environmental conditions. The first excavation campaign started in 2008 with the discovery of the Late Glacial and early Holocene settlements at sites 42 and 11 (Fig. 1) and resulted in the recovery of over 10,000 flint artefacts attributable to various hunter-gatherer groups which settled in the area during the Allerød. These include Federmesser culture materials (two flint concentrations: a domestic unit and a workshop), Swiderian materials, which date to the Younger Dryas (five flint concentrations, mainly domestic units) and Mesolithic materials from the Atlantic period of the Holocene (one small cluster of flints) (Kabaciński and Sobkowiak-Tabaka 2010, 2011). The archaeological remains of the Federmesser complex from the vast area of the North European Plain are dated to between the second half of the Bølling (Greenland Interstadial-GI-1e) and the beginning of the Younger Dryas (GS-1), ca. 12300-10600 cal BC (Sobkowiak-Tabaka 2017). The Swiderian groups appeared in the territory of present-day Poland during the Younger Dryas and the early Preboreal, ca. 10350-9600 cal вC (Sobkowiak-Tabaka 2016).

During the second series of excavations (2011-2014), work moved to the north and site 10 (Fig. 1). Excavations there yielded over 5,000 flints, grouped into 13 concentrations. Five concentrations are related to Federmesser deposits and include a domestic unit, workshops and a hut (ESM 1 Fig. 1.6); the remaining eight concentrations were a result of Swiderian activities (ESM 1 Fig. 1.2-1.5). In the latter case, domestic spaces and workshops were also identified with flint processing, retooling, tool repair and the processing of hard and medium-hard materials occurring in the area (SobkowiakTabaka and Kufel-Diakowska 2019; Diachenko and Sobkowiak-Tabaka 2020; Sobkowiak-Tabaka and Diachenko 2020). The current excavations were carried out between 2017 and 2019, on the northernmost site, 37 (Fig. 1), where archaeological remains from the Hamburg episode at the site were recorded (ESM 1 Fig. 1.1), in addition to Swiderian and Mesolithic settlements. Short surveys in 2012 and subsequent excavations in 2018 and 2019 produced ca. 2,300 flint artefacts.

\section{Materials and methods}

\section{Geomorphology}

The geomorphology of the archaeological site and its surroundings was studied from two $2 \times 2 \mathrm{~m}$ trenches. Trench A 
Fig. 2 a, depth of palaeolake 3; b. thickness of gyttja in palaeolake 5; c, occurrence of basal 2014) peat (after Ratajczak-Szczerba
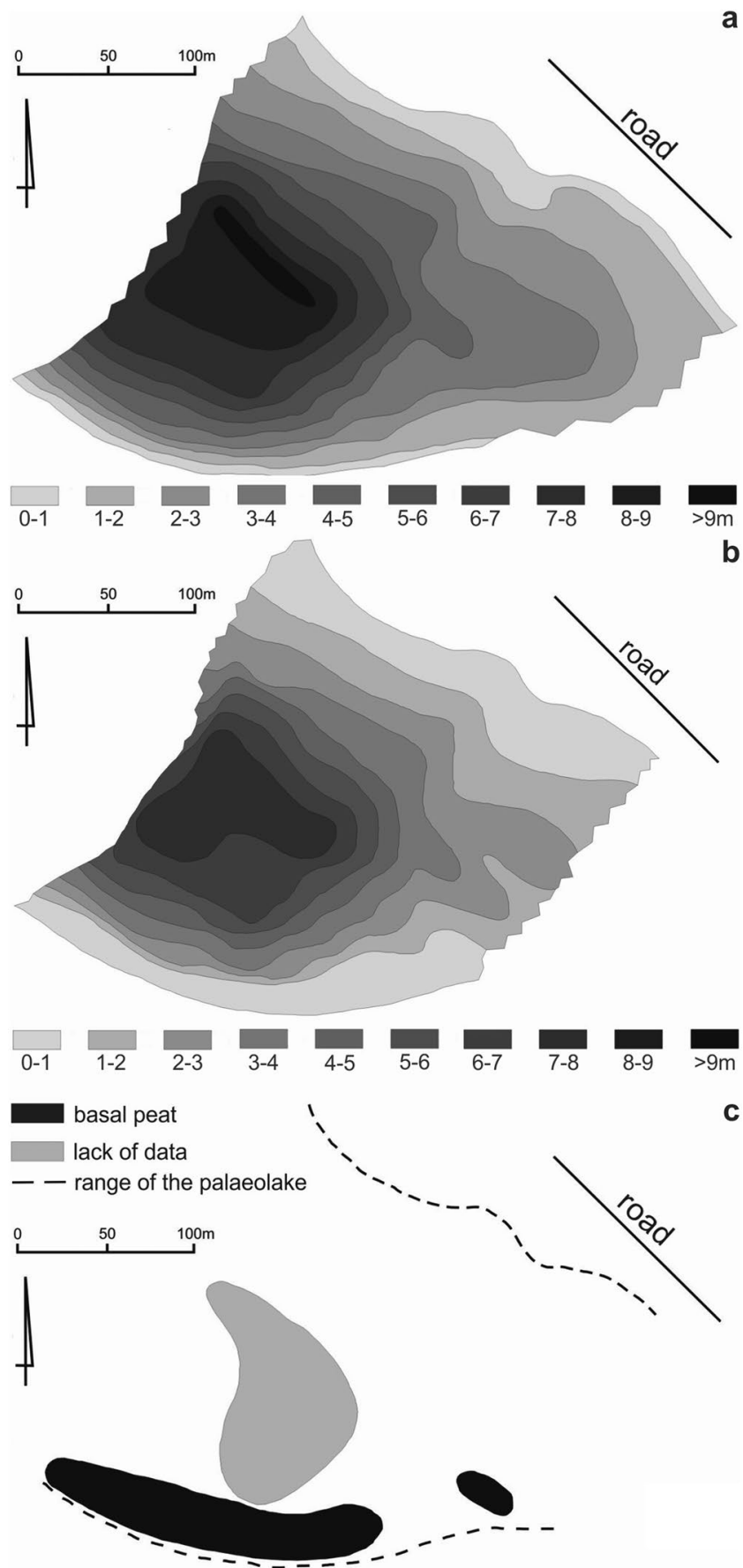

was located on a slope, slightly south of the archaeological excavation, while trench B was located west of the archaeological excavation, on the border between sandy land and a peat plain.

In trench $\mathrm{A}$, the detailed lithofacies analysis of sediments was carried out to a maximum depth of $180 \mathrm{~cm}$, and in trench B, up to a maximum depth of $150 \mathrm{~cm}$. Basic sediment features such as structure and texture were investigated in both trenches using the lithofacies code according to Miall (1985), with further modifications by Zieliński (1995). Ten sediment samples were taken for sedimentological analysis (ESM 2; Fig. 1).

\section{Palaeobiological analyses}

Pollen samples were taken every $2 \mathrm{~cm}$ from sediment core LU 18B, referred to in this study as the master core (Fig. 1). They were prepared according to the standard procedure (Berglund and Ralska-Jasiewiczowa 1986). Mineral content was removed with $\mathrm{HF}$, organic particles with $\mathrm{KOH}$. 
Acetolysis was done for $3 \mathrm{~min}$. Prepared samples were mounted in glycerine and coloured with safranin. Pollen grains were infrequent in the samples, and so at least 300 grains of trees and shrubs (AP) were counted together with all other sporomorphs and NPPs (non pollen palynomorphs); nomenclature of pollen types and algae follows Beug (2004) and Komarek and Jankovska (2001). The zonation was confirmed by CONISS cluster analysis (Grimm 1992) (Fig. 3).

The microscopic charcoal particles were counted together with the pollen and spores under a light microscope at $400 \times$ magnification (by KM). They were further examined under an Olympus transmitted light microscope with a maximum magnification of $600 \times$ at the BIAX Consult laboratory (by LK-M). The sizes of the charred particles were measured for interpretation. On the pollen diagram (Fig. 3), a charcoal accumulation rate is accompanied by a histogram showing the number of charred particles.

After collecting samples for pollen analysis, the remaining material of core LU 18B between 695 and $776 \mathrm{~cm}$ was cut into $1 \mathrm{~cm}$ thick slices for macroremains analysis. The samples were wet sieved using a $250 \mu \mathrm{m}$ mesh at the BIAX Consult laboratory. The macroremains were identified under a Leica binocular microscope at magnifications of $\times 6$ to $\times 60$. All identifications were made using relevant literature (Beijerinck 1947; Berggren 1969, 1981; Cappers et al. 2006) and modern reference material. The results of the plant macrofossil analyses are given as the number of remains per constant sample volume (Fig. 4). The plant taxa are arranged in ecological groups: trees and shrubs, herbaceous plants and aquatics. During the analysis, some plant macroremains were selected for AMS ${ }^{14} \mathrm{C}$ dating.

The diatom samples from the master core were prepared according to standard methods (Battarbee 1986). The counting method of Schrader and Gersonde (1978) was used; between 300 and 500 valves were counted in each sample in order to estimate the percentage abundance of particular taxa (Fig. 5). The diatoms were divided into groups according to their biotype requirements; planktonic, periphytonic and benthic groups were distinguished (Round 1981). Diatoms were grouped by their $\mathrm{pH}$ requirements according to Hustedt (1939), water nutrient status according to Naumann (1932) and amount of organic material according to Kolkwitz and Marsson (1908). Local diatom assemblage zones (LDAZs) were distinguished by differences in the taxon composition, the relative frequencies of the taxa and the prevalent ecological and habitat groups (Bakk et al 2012).

For Cladocera analysis, $1 \mathrm{~cm}^{3}$ samples of fresh sediment were taken at $2 \mathrm{~cm}$ intervals from the master core and were processed according to standard procedures (Frey 1986). The extracted remains were identified after Szeroczyńska and Sarmaja-Korjonen (2007), van Damme and Dumont (2008), van Damme et al. (2010) and Faustova et al. (2011). All skeletal elements such as the head shield, shell, post-abdomen, claw and ephippium in each sample were counted and used to calculate the number of individuals per $\mathrm{cm}^{3}$ of fresh sediment (Fig. 6). Classification of Cladocera habitat preferences followed Flössner (1972, 2000), Bjerring et al. (2009) and Błędzki and Rybak (2016). Additionally, achydorid carapaces (representing asexual reproduction) and ephippia (representing sexual reproduction) were counted, and the total sum of chydorid ephippia (TCE) was calculated from the sum of chydorid shells and ephippia (Sarmaja-Korjonen 2003).

Mollusc shells from the master core were identified under a Nikon SMZ 1500 stereoscopic microscope at magnifications of 7.5-112.5 $\times$. The analysis used standard methods described by Alexandrowicz and Alexandrowicz (2011). The shell remains were identified according to Piechocki and Wawrzyniak-Wydrowska (2016) and Gittenberger et al. (2004) and by using the reference collection, and in addition to their ecological and palaeoenvironmental contexts were described in accordance with Ložek (1964), Alexandrowicz (1987) and Alexandrowicz and Alexandrowicz (2011); Fig. 7.

\section{Carbon and oxygen stable isotope analyses}

Due to the insufficient number of mollusc shells preserved in core LU 18B, shells from core LB 13 were selected for analysis. There is a chronological correlation between the two cores (Allerød). Carbon and oxygen stable isotope compositions of Valvata cristata and V. piscinalis shell carbonates were measured using a Gas Bench II attached to a Finnigan MAT 253 gas source mass spectrometer (both Thermo Fischer) (ESM 3). Details of the analytical setup are given in Spötl and Vennemann (2003). Carrara marble was analysed with the samples, and its isotopic composition was calibrated against NBS 19 (Fiebig et al. 2005). All values are reported in $\delta$ notation, where $\delta=\left(\mathrm{R}_{\text {sample }} / \mathrm{R}_{\text {standard }}-1\right) \times 1,000$, in per mil relative to V-PDB (Vienna Pee Dee Belemnite) carbonate standard and have an analytical precision of $\pm 0.06 \%$ o for carbon and $\pm 0.08 \%$ o for oxygen.

\section{Geochemical analyses}

Geochemical analyses of the master core included the measurement of organic matter, calcium carbonate, the contents of terrigenous (soil) and biogenic silica, in addition to the metals, sodium $(\mathrm{Na})$, potassium $(\mathrm{K})$, magnesium $(\mathrm{Mg})$, iron $(\mathrm{Fe})$ and manganese $(\mathrm{Mn})$. Loss on ignition (LOI) was measured, as dried organic matter samples combusted at $550{ }^{\circ} \mathrm{C}$ while the calcium carbonate combusted at $950{ }^{\circ} \mathrm{C}$ (Heiri et al. 2001). The total silica content was measured using digestion in aqua regia (1:3 nitric and hydrochloric acid) in a water bath, while terrigenous silica content was measured after dissolving biogenic silica in a sodium hydroxide 


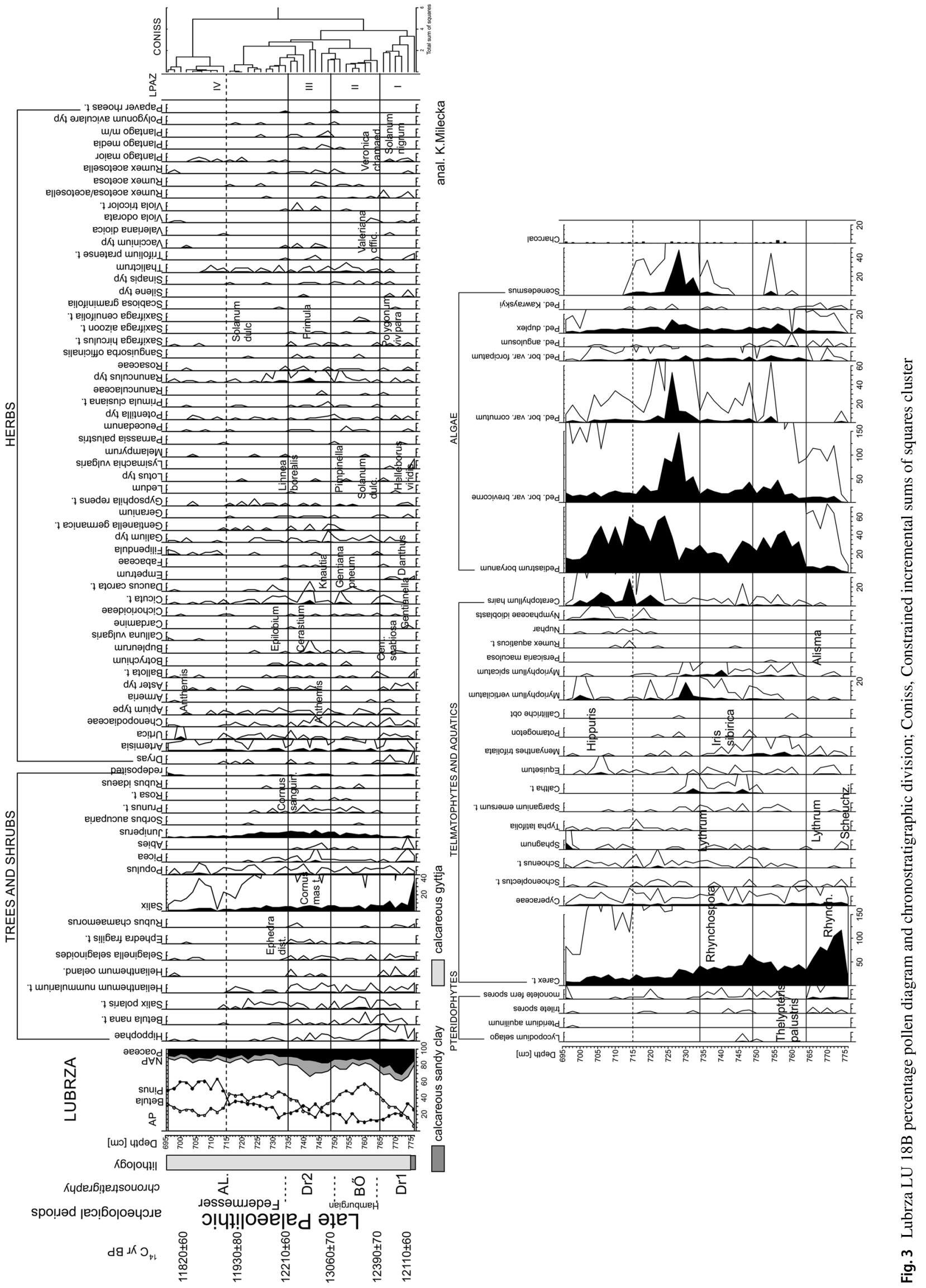




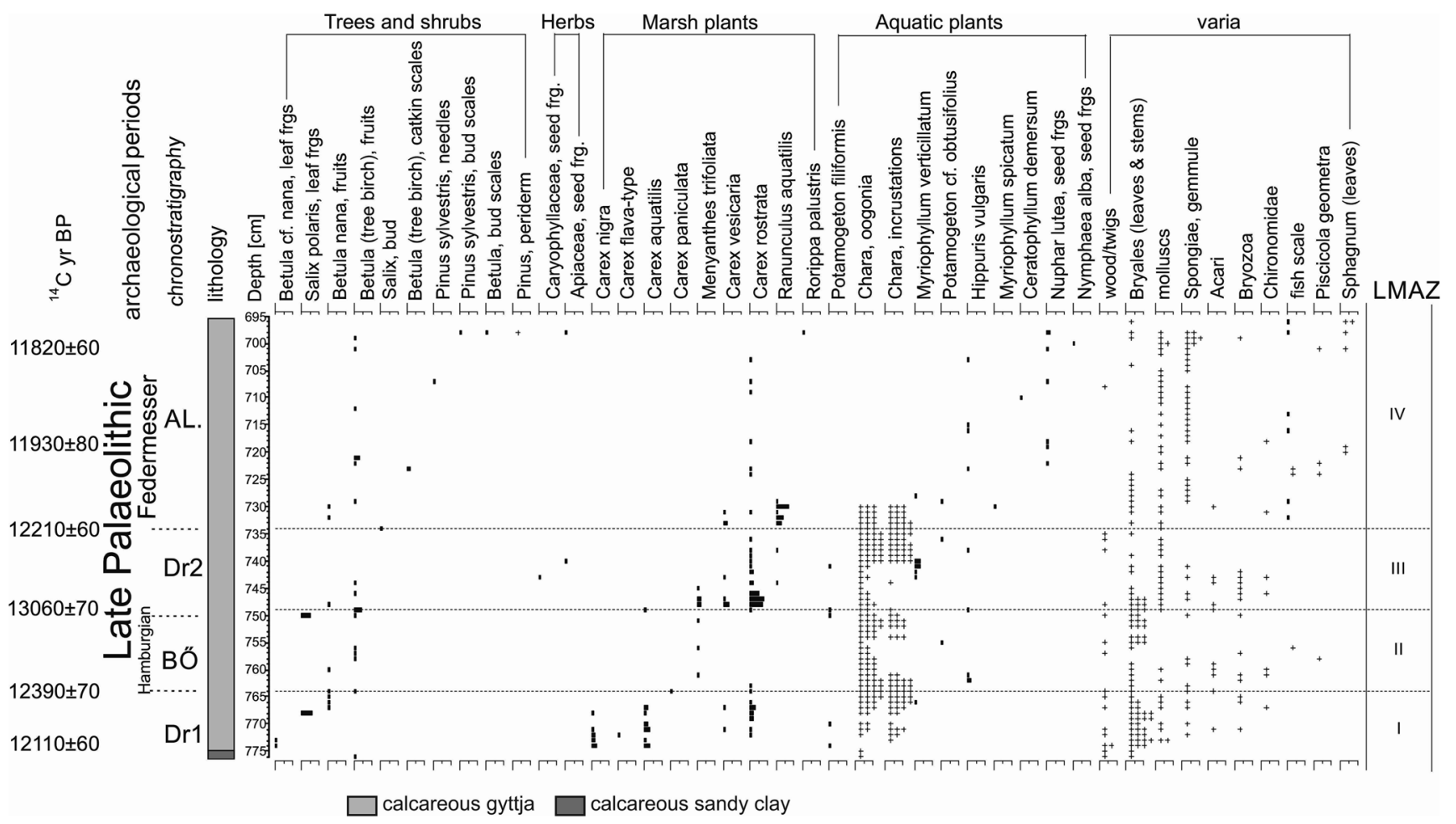

Fig. 4 Lubrza LU 18B macroremains diagram and chronostratigraphic division

solution. The metal contents were determined in digested liquid samples using flame atomic absorption spectrometry. The constrained hierarchical clustering algorithm implemented in the R package rioja (Juggins 2017) was used to determine local geochemical units (Fig. 8).

\section{Results and interpretation}

\section{Lithology}

The stratigraphy of archaeological site 37 shows that the top layers were built of medium sands, redeposited from erosion. Below the top layers are finer sediments, fine sand and silt, whose grain size and structural features indicate deposition by water associated with deglaciation of the area.

A similar sediment stratigraphy was observed at the Lubrza 10 site, which is located on a sandy bank. Due to the thinner redeposited material, a deeper series of sediments built up in the channels between the blocks of dead ice. These series were identified as part of this project, including fissures and faults indicating that they are eskers, mounds of sand gravel and till deposited from streams running under ice (Ratajczak-Szczerba et al. 2015; Sobkowiak-Tabaka et al. 2018). The geomorphological study of archaeological site 37 shows a similar landform type.
The location of Lubrza site 37 indicates that it was not on the highest point, but lower down, further along the sandy headland stretching out into the peat plain. The difference in relative height between the lowest point in the adjacent glacial channel and the site itself is over $5 \mathrm{~m}$.

The basal sediments of master sequence LU 18B were formed of calcareous sandy clay $(776-775 \mathrm{~cm}$ ), which was followed by accumulation of calcareous gyttja $(775-696 \mathrm{~cm})$.

\section{Radiocarbon dates}

Six AMS radiocarbon dates were obtained from waterlogged terrestrial plant macroremains from core LU 18B (Table 1). They were calibrated with IntCal20 (Reimer et al. 2020) and OxCal v 4.4.2 (Bronk Ramsey 2009). Dates are given in calibrated years ВС (Table 1). The age-depth model was constructed using the free shape modelling algorithm (Fig. 9; Goslar et al. 2009).

The results of the six radiocarbon dates provide an absolute chronology for the record, which includes the Oldest Dryas up to the late Allerød. Unfortunately, the two lowest dates from the lower part of the LU 18B sequence (5 and 6) show a clear age reversal (Table 1), and the position of date 4 in the sequence is problematic. Even though contamination in the field cannot be completely excluded, there might be other reasons for this date 'migration' through the lower part 


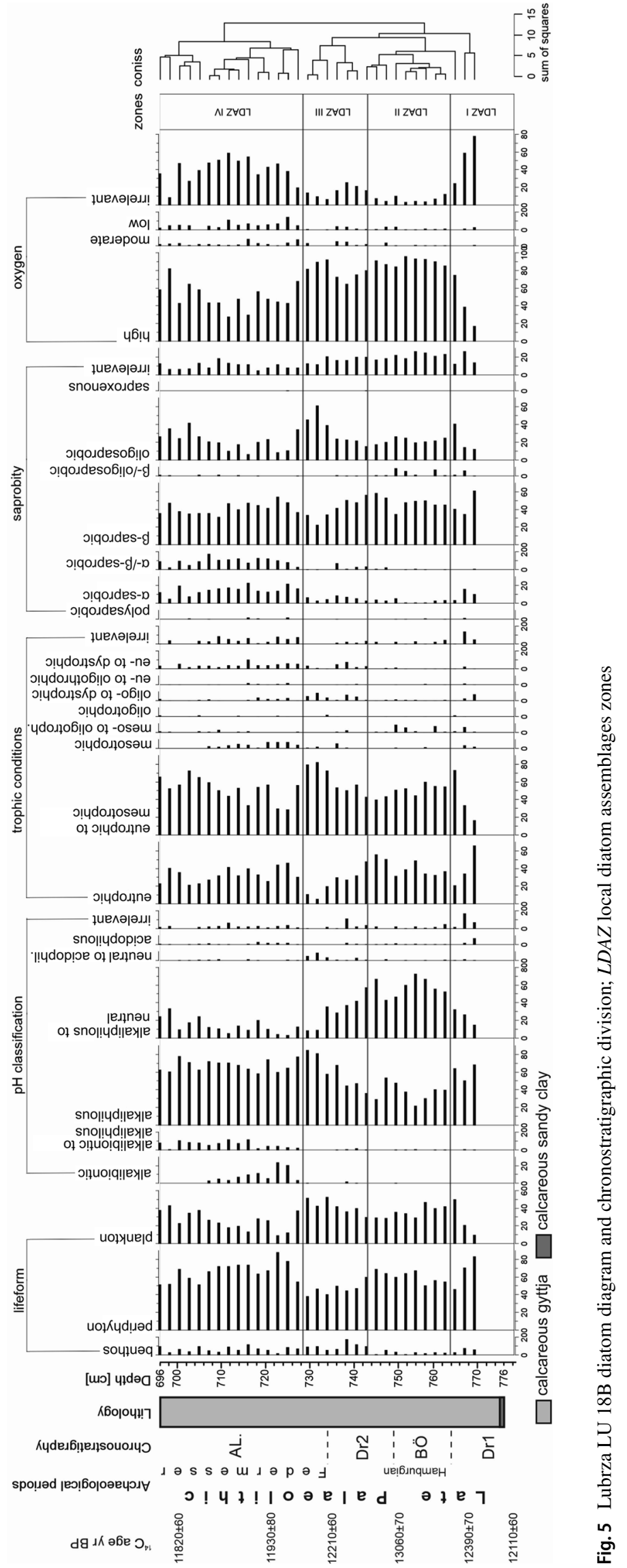




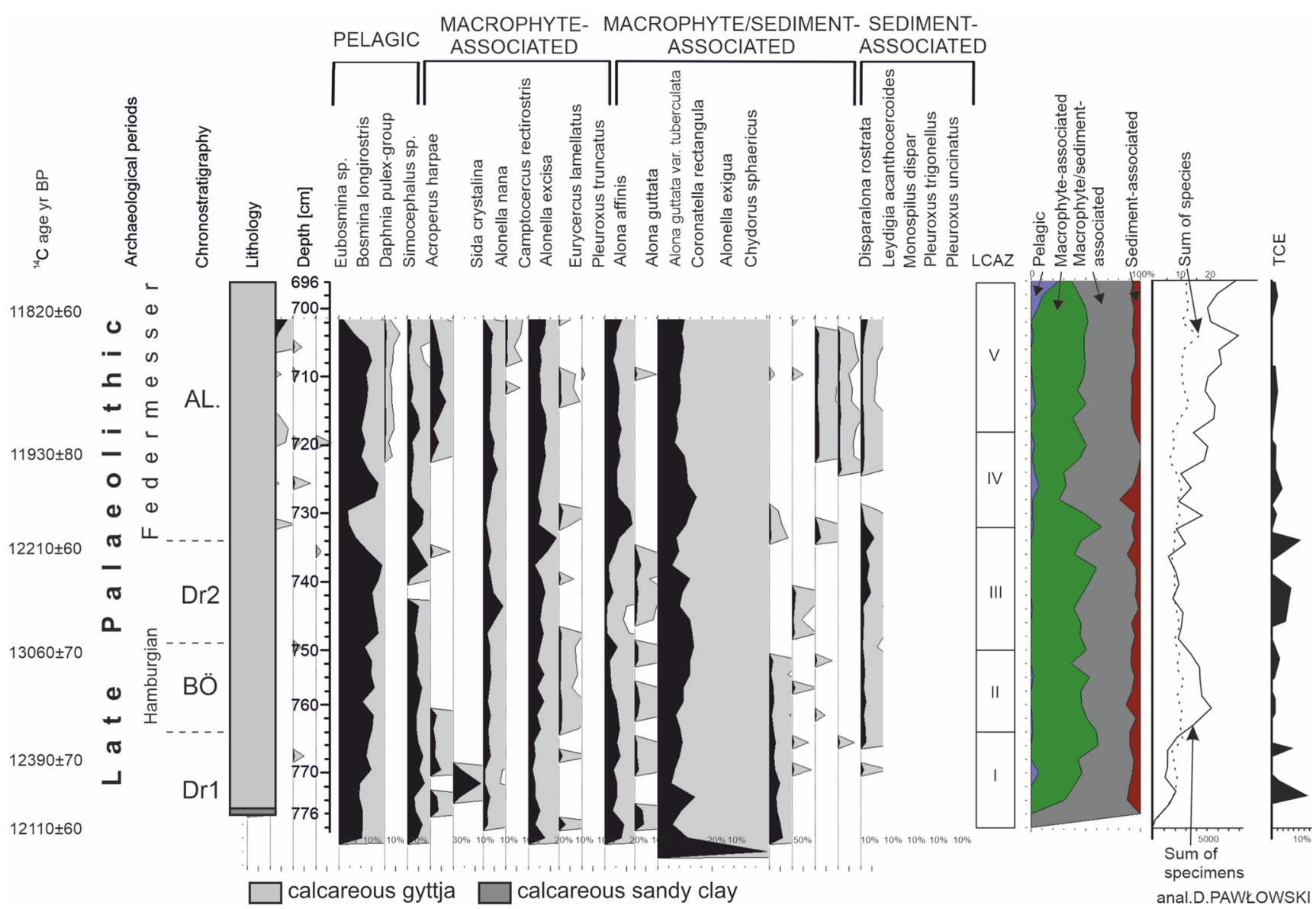

Fig. 6 Lubrza LU 18B Cladocera percentage diagram, total sum of taxa and specimens and chronostratigraphic division; LCAZ local Cladocera assemblage zones

Fig. 7 Lubrza LU 18B mollusc diagram and chronostratigraphic division; $M Z$ malacological zones

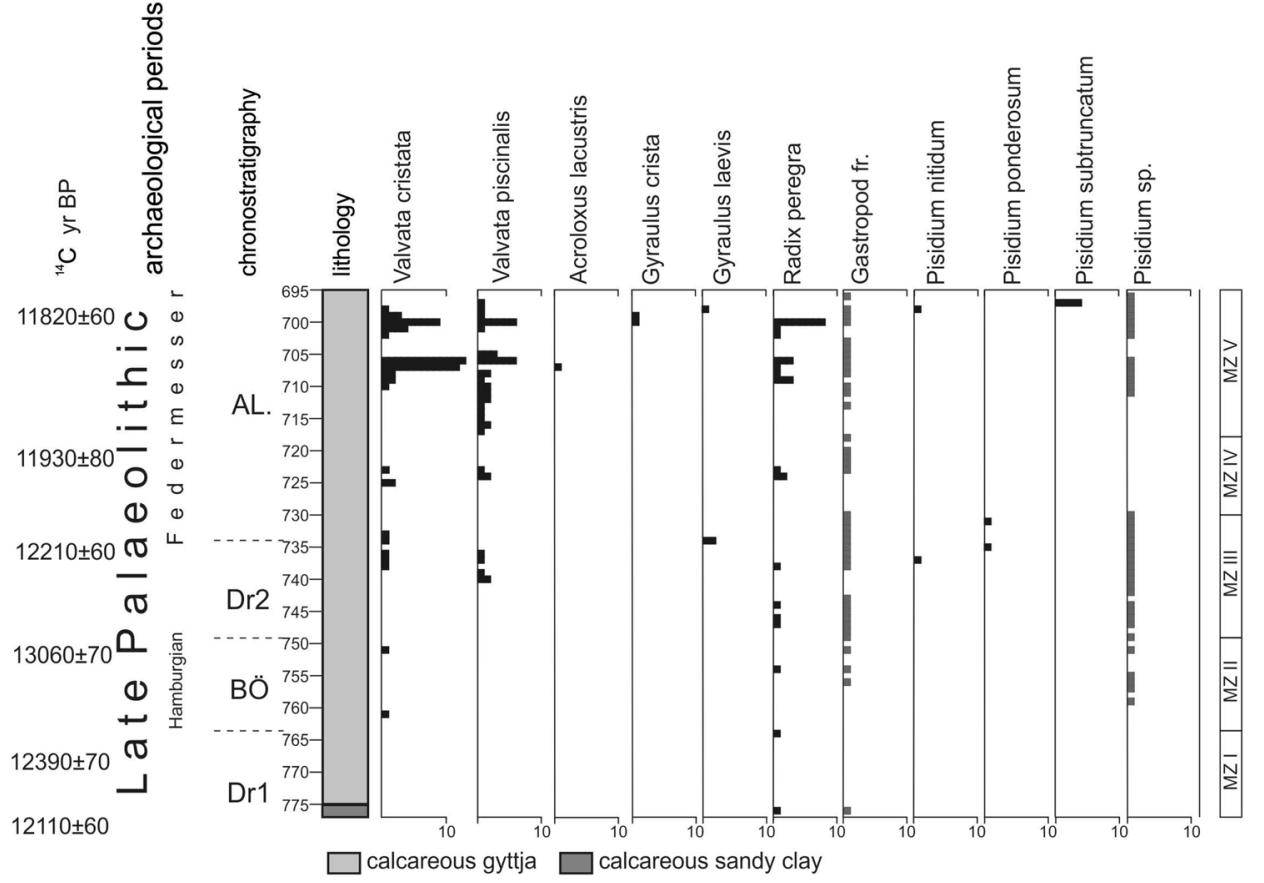




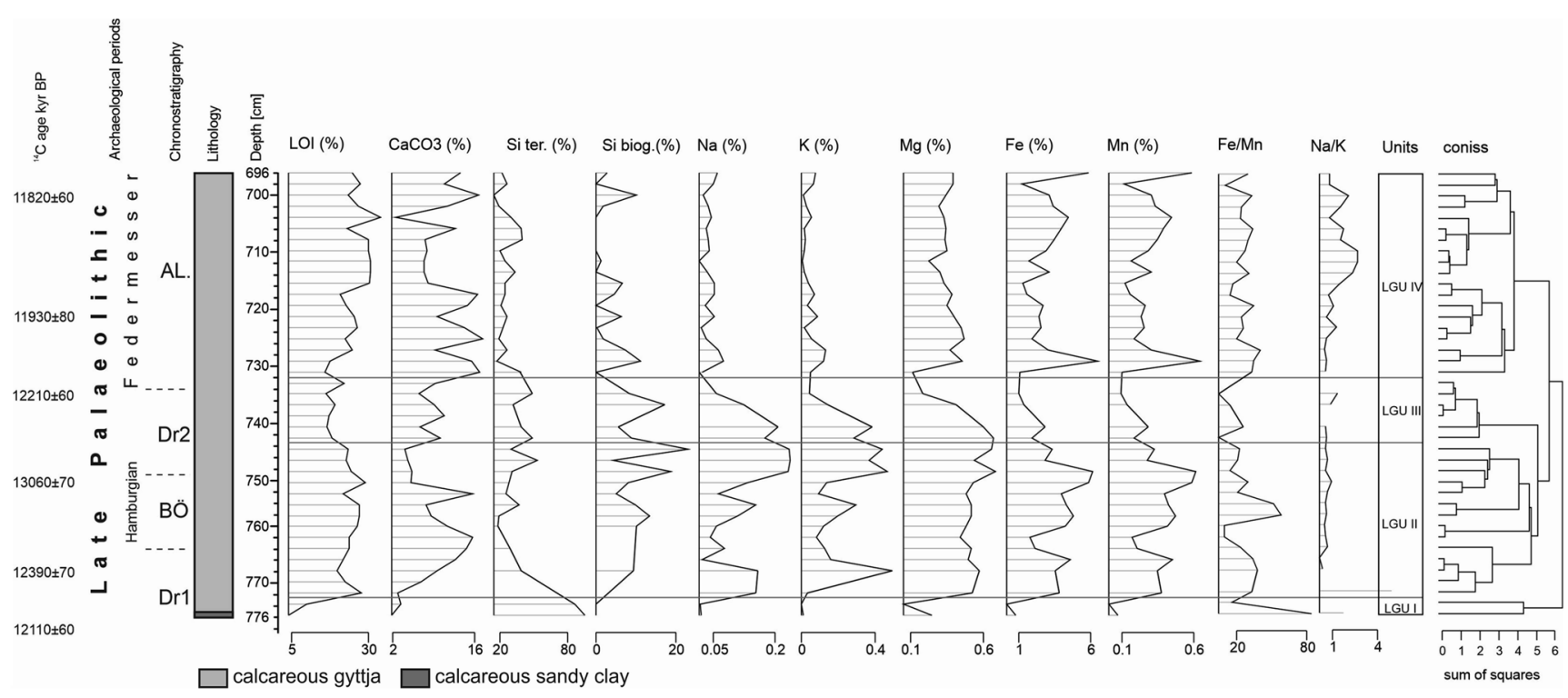

Fig. 8 Lubrza LU 18B geochemical data; LGU, local geochemical units

Table 1 Radiocarbon dated samples from Lubrza LU 18B

\begin{tabular}{|c|c|c|c|c|c|}
\hline No & Depth $(\mathrm{cm})$ & Plant remains (all un-charred) & Weight & ${ }^{14} \mathrm{C}$ age (years BP) & Calibr. age $\mathrm{BC}^{*}$ \\
\hline 1 & $700-709$ & $\begin{array}{l}\text { Pinus sylvestris needle } 1 \mathrm{frg} \text {, Betula (tree birch) fruit } 1 \mathrm{x} \text {, cf. Salix } \\
\text { twig } 1 \mathrm{frg}, \text { Carex rostrata } 3 \mathrm{x}\end{array}$ & c. $2 \mathrm{mg}$ & $11,820 \pm 60$ & $11,845-11,564$ \\
\hline 2 & $721-724$ & Betula (tree birch) fruit $4 \mathrm{x}$, catkin scales $2 \mathrm{x}, C$. rostrata $2 \mathrm{x}$ & c. $2 \mathrm{mg}$ & $11,930 \pm 80$ & $12,074-11,656$ \\
\hline 3 & $735-740$ & C. rostrata $3 \mathrm{x}, \mathrm{cf}$. Salix twig $3 \mathrm{frg}$ & c. $2 \mathrm{mg}$ & $12,210 \pm 60$ & $12,837-11,928$ \\
\hline 4 & $750-758$ & $\begin{array}{l}\text { cf. Salix twig } 2 \mathrm{frg} \text {, Betula (tree birch) fruit } 4 \mathrm{x} \text {, Menyanthes trifoliata } \\
1 \mathrm{x} \text {, deciduous leaf (cf. Salix) } 5 \mathrm{frg}\end{array}$ & c. $3 \mathrm{mg}$ & $13,060 \pm 70$ & $13,922-13,424$ \\
\hline 5 & 768 & Salix twig $6 \mathrm{frg}$, C. rostrata $2 \mathrm{x}$, C. acuta/nigra $1 \mathrm{x}$, C. aquatilis $1 \mathrm{x}$ & $16 \mathrm{mg}$ & $12,390 \pm 70$ & $12,964-12,212$ \\
\hline 6 & $776-777$ & Salix-twig $8 \mathrm{frg}$, Betula (tree birch)-fruit $1 \mathrm{x}$ & $8 \mathrm{mg}$ & $12,110 \pm 60$ & $12,159-11,853$ \\
\hline
\end{tabular}

Ages have been calibrated (IntCal13; 95.4\% probability) using OxCal v 4.3 (Bronk Ramsey 2008)

of the sequence, such as redeposition of the dated plant macroremains in a highly dynamic sedimentary environment. Age reversal in Late Glacial sequences has been observed quite often (Bos et al. 2017). In the case of the Lubrza palaeolakes (but possibly also other regions), the disturbance in biostratigraphy may be related to the melting process of the dead ice blocks during the pre-Allerød period. The course of events, which resulted in the formation of palaeolakes during the Late Glacial is often described as dynamic in nature, and accompanied by erosion processes (Błaszkiewicz 2007). Therefore, correlation of the ${ }^{14} \mathrm{C}$ radiocarbon dates with the pollen zones was essential for the reconstruction of the climatic and environmental events in the Lubrza area.

The age reversal in the LU $18 \mathrm{~B}$ sequence resulted in the construction of two age-depth models, rejecting the date of either sample 5 or 6 . Figure 9 presents a combined model, assuming that both scenarios are equally likely. As a result, it has a high level of uncertainty at the bottom of the dated core. Keeping this uncertainty in mind, the diagrams of analytical results obtained along the profile are presented on a timescale which is averaged between the two scenarios mentioned above. Numerical data of the most probable (best-fit) partial models are presented in ESM 4.

\section{Palaeobiological and geochemistry data}

The results of the analyses of pollen, plant macrofossils, diatoms, Cladocera, molluscs and geochemistry from core LU 18B are presented in Figs. 3, 4 and 6-9. More detailed descriptions of the results are presented in ESM 5.

Reconstruction of regional and local vegetation and the history of the palaeolake at Lubrza.

Due to apparent age reversal of the radiocarbon dates in the lower part of the sequence, this environmental reconstruction is based on the palynological results of 
Fig. 9 Age-depth model of profile Lubrza LU 18B in years cal BC shown by solid black line. Grey filled curves represent calibrated ${ }^{14} \mathrm{C}$ dates of individual samples used for the modelling. Two best-fit age-depth curves (calculated after rejection of either sample 5 or 6 ) are shown with dotted lines. Uncertainty of the combined model is displayed with grey shading

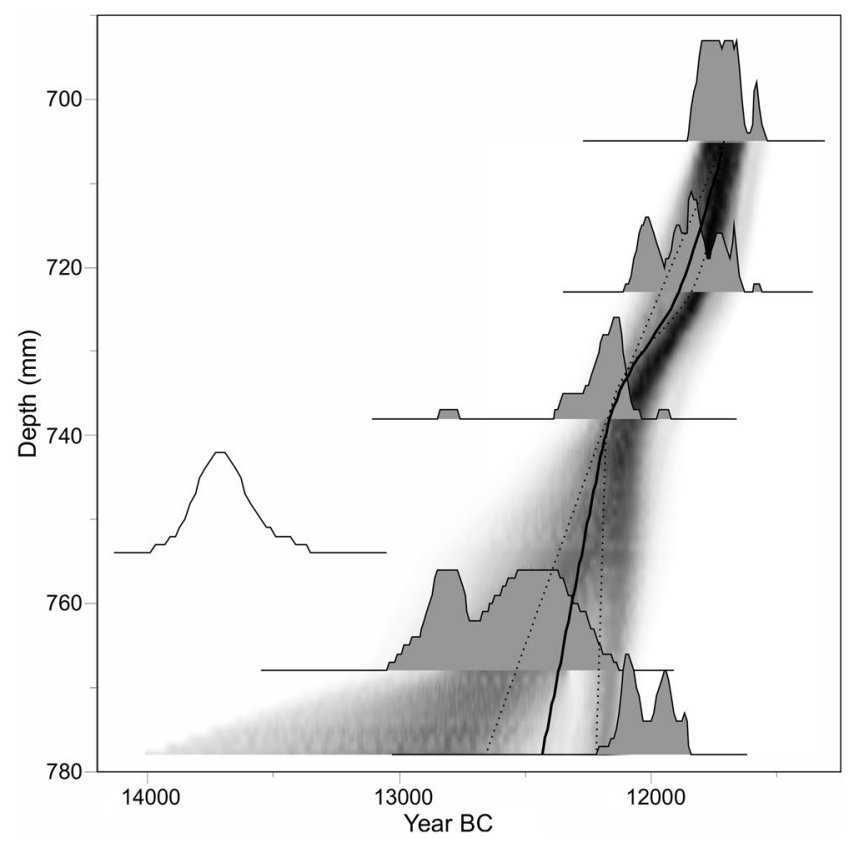

harpae, Alona affinis and Chydorus sphaericus (Whiteside 1970). These conditions are confirmed by the highest proportion of total chydorid ephippia (TCE) in the profile. However the middle part of this period sees a gradual increase in the frequencies of Cladoceran taxa associated with aquatic plants (macrophytes), which suggests a corresponding increase in plant life in this part of the palaeolake.

The appearance of molluscs coincides with the accumulation of gyttja during this period. However, single shell fragments identified in the samples suggest that environmental conditions were not conducive to molluscs. The habitat preferences of the diatom assemblage suggest that water levels were relatively high, and the taxon composition reflects an alkaline and eutrophic water environment.

The geochemical analysis reveal distinct fluctuations in soluble metals, $\mathrm{Na}$ (sodium), $\mathrm{K}$ (potassium), and $\mathrm{Mg}$ (magnesium); these are probably the result of intensive mineral soil erosion in the catchment area. Jones and Keen (1993) interpret substantial quantities of sodium and potassium in sediments as the result of intensive erosion of mineral soil and a low level of leaching.

\section{Bølling (corresponding to LPAZ II)}

Betula pollen dominates the Bølling samples, and the presence of Betula cf. pubescens macrofossils suggest that birch trees also grew in the landscape. The pollen and macrofossil assemblages also prove the presence of $B$. nana (dwarf birch). This suggests that tundra vegetation still existed in the area, and $B$. nana grew together with dwarf shrubs of Salix (willow) and H. nummularium, and sporadically with Dryas octopetala, all present in the pollen record. Scattered ronmental stress, including cold climate, such as Acroperus 
patches of Juniperus shrubs grew among the birches and patches of Hippophaë were also present in the landscape.

The range of Betula could also have been determined by soil conditions. Birches avoid soil rich in lime, although such soils are suitable for Hippophaë (Usinger 1985). Eventually, Hippophä̈ was shaded out by more competitive taxa such as Populus and Betula trees. Selaginella selaginoides (clubmoss) appeared in wet habitats such as bogs, wet slopes and lake shores with neutral to alkaline soil (Hitchcock et al. 1969). Ephedra fragilis grew in warm steppe-like habitats rich in calcium, accompanied by Poaceae and Artemisia. Diverse aquatic plants were identified, including Potamogeton filiformis, $P$. cf. obtusifolius, Hippuris vulgaris (macrofossil record), Myriophyllum spicatum, Ceratophyllum and Potamogeton (pollen record), along with increasing values of Pediastrum. Overall, this indicates increased levels of aquatic productivity (cf. Krüger and Damrath 2020). An abundance of green algae (Chara sp.) indicates an increase in calcium carbonate precipitates (Hoek et al. 1999), which is confirmed by higher calcium carbonate content and organic matter in unit LGU II. The further soil erosion and weathering of the catchment was confirmed by the high content of some elements and a low $\mathrm{Na} / \mathrm{K}$ ratio.

An increase in more Cladocera species associated with plants, such as Camptocercus rectirostris, Eurycercus lamellatus and Alonella nana suggest well developed vegetation along the lake shore. Leydigia acanthocercoides, Monospilus dispar, Coronatella rectangula, Chydorus sphaericus and taxa of the genus Pleuroxus suggests an increase in the nutrient level of the lake water. This situation was connected with a decreasing TCE (total chydorid ephippia). All of this might suggest a milder climate and warmer waters.

The most common diatoms were periphytonic forms (55-69\%), followed by planktonic ones (30-40\%). Their trophic tolerance is broad, from eutrophic to mesotrophic, while their $\mathrm{pH}$ tolerance is alkaline to neutral. They indicate very high water oxygenation.

Among the molluscs, single shell fragments of taxa associated with lake shore and aquatic vegetation (macrophytes) suggest slightly improved environmental conditions.

\section{Older Dryas (corresponding with LPAZ III)}

During the Older Dryas, the climate generally cooled. Patches of birch trees diminished, as evidenced by the presence of birch tree macroremains only at the beginning of this period. Tundra vegetation was again a dominant vegetation cover, and dwarf shrub patches with Betula nana and Dryas octopetala again developed in the area. Cold tolerant taxa increased in their percentages, including among herbs, with Gentianella germanica-type, Gypsophila fastigiata, Saxifraga aizoon and $S$. hirculus. These suggests the development of mires, where Betula nana, Rubus chamaemorus,
Cyperaceae and Sphagnum would also have been found. Ephedra fragilis-type is present during the entire Older Dryas phase.

In lake shore zones and wet habitats, Menyanthes trifoliata persisted and Caltha palustris developed. Sedges, including Carex rostrata, $C$. vesicaria and $C$. aquatilis grew on the wet soils by the lake. Myriophyllum spicatum and Ceratophyllum dominated the aquatic plants, as indicated by the pollen record. They were accompanied by M. verticillatum, Potamogeton filiformis, P. cf. obtusifolius and Hippuris vulgaris, based on macrofossil evidence.

The visible decrease in the number of Cladoceran species, together with an increasing number of TCE (total chydorid ephippia), suggests a decrease in water trophic level, overall cooler waters, and perhaps a shorter open water season in the lake.

The identified diatom assemblages confirm relatively wide trophic tolerance, from eutrophic to mesotrophic. The $\mathrm{pH}$ was alkaline to neutral.

The molluscs are associated mainly with aquatic vegetation (Radix peregra, Valvata cristata), but the presence of the cold tolerant species Gyraulus laevis confirms cooler climatic conditions. The presence of Pisidium ponderosum indicates a shallow place in the littoral zone, with a sandy substrate and water rich in calcium.

The geochemical composition with decreasing contents of elements derived from stone suggests a limited influx of erosion and relatively good oxygen conditions in the lake.

\section{Allerød (corresponding with LPAZ IV)}

The start of the Allerød is marked by a significant decrease in cold-tolerant taxa. The older part of the Allerød reveals the dominant role of Betula and the absence of Pinus. The macrofossil record also proves the local presence of Betula trees (B. cf. pubescens) in the Lubrza area, which were accompanied by Pinus sylvestris (Scots pine) through the second half of the Allerød. Woodlands, however, remained relatively open, but the low NAP sum suggests decreased proportions of herbaceous taxa.

During the Allerød, Ceratophyllum and M. spicatum dominated the macrophyte pollen record. The macrofossil record also indicates the presence of Nymphaea alba and Nuphar lutea, Hippuris vulgaris and $C$. demersum. The diversity of aquatic plants indicates well-developed plant communities with submerged plants in the deeper parts of the palaeolake and communities of plants with floating leaves in the shallow areas. Marsh vegetation with herbaceous plants such as Carex rostrata, C. vesicaria, Ranunculus aquatilis and Rorippa palustris spread along the shores of the lake.

The presence of Typha latifolia (in the pollen record) since the start of the Allerød indicates an increase in 
temperature compared with the Older Dryas, and the warmest climate during the entire Late Glacial. Iversen (1954) and Wasylikowa (1964) considered this species an indicator of a mean July temperature of $+14{ }^{\circ} \mathrm{C}$.

Aquatic invertebrates are dominated by benthic phytophilic Cladoceran taxa which are associated with the littoral zones of eutrophic lakes, and they are considered trophic indicators (Fig. 6). Generally, the Cladoceran taxa suggest warm summers, with a long open-water season and a high lake trophic level or an exceptionally warm and long growing season, which ultimately could also be a response to climatic amelioration.

Some noticeable changes at a depth of $722 \mathrm{~cm}$ indicate a cold period, possibly the Gerzensee oscillation. The NAP increases, mainly due to the higher Poaceae curve. Birch trees ceased to dominate the landscape as cold tundra vegetation developed, with the dwarf shrub Salix (S. polaristype). The pollen data indicate a short interruption in Typha latifolia just before the Gerzensee oscillation (Fig. 6). A decrease in the number of Cladoceran taxa was noted, especially those which are associated with warm water (Camptocercus rectirostris, taxa of Pleuroxus) and more eutrophic waters (Monospilus dispar, Corotella rectangula). This coincides with a decrease of TCE (total chydorid ephippia) and an increased abundance of species (Acroperus harpae and Chydones sphaericus) that are tolerant of environmental stress, including cold climate (Pawłowski 2012).

The mixture of molluscan taxa with various environmental requirements from palaeolakes 1 (LB 13) and 3 (LU 18) relates to an increase in habitat diversity during the second part of the Allerød. All the molluscs identified in the samples are characteristic of rather shallow lakes, but their limited and changing numbers suggest poor dispersal, probably due to climatic conditions.

Changes in the climate are clearly reflected in the $\delta^{18} \mathrm{O}$ shell record from core LB13 (ESM 3). Diatoms reveal the relatively high contribution of periphytonic taxa. The most abundant ones were typical of eutrophic to mesotrophic waters and a moderate level of organic material. Geochemical studies revealed smaller amounts of sodium and potassium in this core section, linked to reduced erosion and enhanced leaching, and slight deterioration of the oxygen supply.

\section{Younger Dryas}

The cooler climate during the Younger Dryas introduced changes in the landscape, which are reflected in cores L-33/2 and LB 13, taken from palaeolake 1, ca. $400 \mathrm{~m}$ from the location of core LU 18B (Fig. 1). The woodland cover was clearly reduced and the spread of juniper and the growth of both Artemisia patches and areas dominated by grasses are indicated by the pollen spectra. Betula nana was part of the local vegetation. Various sedges (Carex aquatilis, C. vesicaria, $C$. rostrata, $C$. paniculata/diandra) accompanied by Selaginella selaginoides grew not only on the wet soil along the lake shore but also in bogs or mires, which formed part of the local vegetation.

During the Younger Dryas, a rich mollusc fauna is indicated by both the high diversity of taxa and large quantities of mollusc remains (LB 13). At the beginning of the phase, larger permanent bodies of water were formed due to the cooler climate (Sobkowiak-Tabaka et al. 2018), probably connected with a rise in lake water levels correlated with increased precipitation at the end of the Late Glacial. As a result, small ponds transformed into larger and deeper bodies of water (lakes), which began to accumulate carbonate sediments (Alexandrowicz 2007). The molluscs of this period are associated with rich aquatic vegetation. Cooler conditions are confirmed by the presence of Pisidium obtusale lapponicum and Gyraulus laevis. The cold Younger Dryas is also recorded by a ca. 0.5 to $1.5 \%$ decrease in $\delta^{18} \mathrm{O}$ values. Low and relatively stable $\delta^{18} \mathrm{O}$ values recorded in the older part of this chronozone (mean $\delta^{18} \mathrm{O}$ value $-10.65 \%$ ) are consistent with other European records (Schwander et al. 2000; Apolinarska and Hammarlund 2009; Słowiński et al. 2017).

\section{Evidence of human activity during the Late Glacial in the Lubrza area}

Palynological evidence for human activity is not obvious in the early prehistoric period, before the Neolithic. Some assumptions are possible, based on the presence of nitrophilous or eutrophic plants. Increases in such taxa are seen especially during the warmer periods of the Late Glacial. High curves of Pediastrum boryanum with its subspecies and Scenedesmus are found during Bølling and Allerød and they could be the result of the eutrophication of the lake due to repeated human presence. However, one must consider the possibility of increased Pediastrum content also being due to the inflow of nutrients from the catchment as a result of warming or erosional processes (Hosek et al. 2014; Karasiewicz 2019; Mirosław-Grabowska et al. 2020). Pollen records of some plants could also suggest traces of changes from human activities. Urtica (nettle) responds to nitrogenenriched soils, which would have been found around the camps as a natural consequence of remnants of food and faeces. Plantago major and Polygonum aviculare are characteristic of places trodden by people such as paths, so perhaps their appearance was partly due to human pressure. We must remember, however, that the pressure of migrating people on habitats and vegetation was very limited and such an interpretation for the presence of eutrophic taxa is only a suggestion.

The pollen analysis revealed that the pollen slides also contained microscopic charcoal particles which were not 
found at the macroscopic level. No charcoal or other charred plant remains were found in the macroremain samples. In the pollen slides, the charred particles were recognised by their sharply broken edges and black or dark brown colour (Figs. 10,11). With a few exceptions of charred herbaceous tissues, they are all derived from wood charcoal. Some of the charcoal particles revealed the presence of bordered pits (Fig. 10, left). These are cavities or thinner portions in the lignified cell walls of the xylem elements in coniferous wood (Schweingruber 1990). The Late Glacial saw the spread of two coniferous taxa in north central Europe, Pinus and Juniperus (Huntley and Birks 1983; Lang 1994). Both taxa are well represented in the Late Glacial pollen records from western Poland (Sobkowiak-Tabaka et al. 2018). The plant macroremains assemblages from nearby Lubrza LB 13 and from the Wojnowo region some $30 \mathrm{~km}$ south-east of Lubrza further indicate that Pinus sylvestris and Juniperus communis (juniper) were the only conifers in the woody vegetation of western Poland throughout much of the Late Glacial (Kubiak-Martens 2016; Sobkowiak-Tabaka et al. 2018). However, considering the occurrence of the coniferous charcoal in the LU 18B core section, palynologically defined as Bølling, when pine was not yet present in the area, we assume that the charcoal particles featuring the bordered pits must have derived from juniper.

Different sizes of microscopic charcoal particles were observed on the pollen slides. The diameters of 100 randomly selected particles were measured, resulting in three

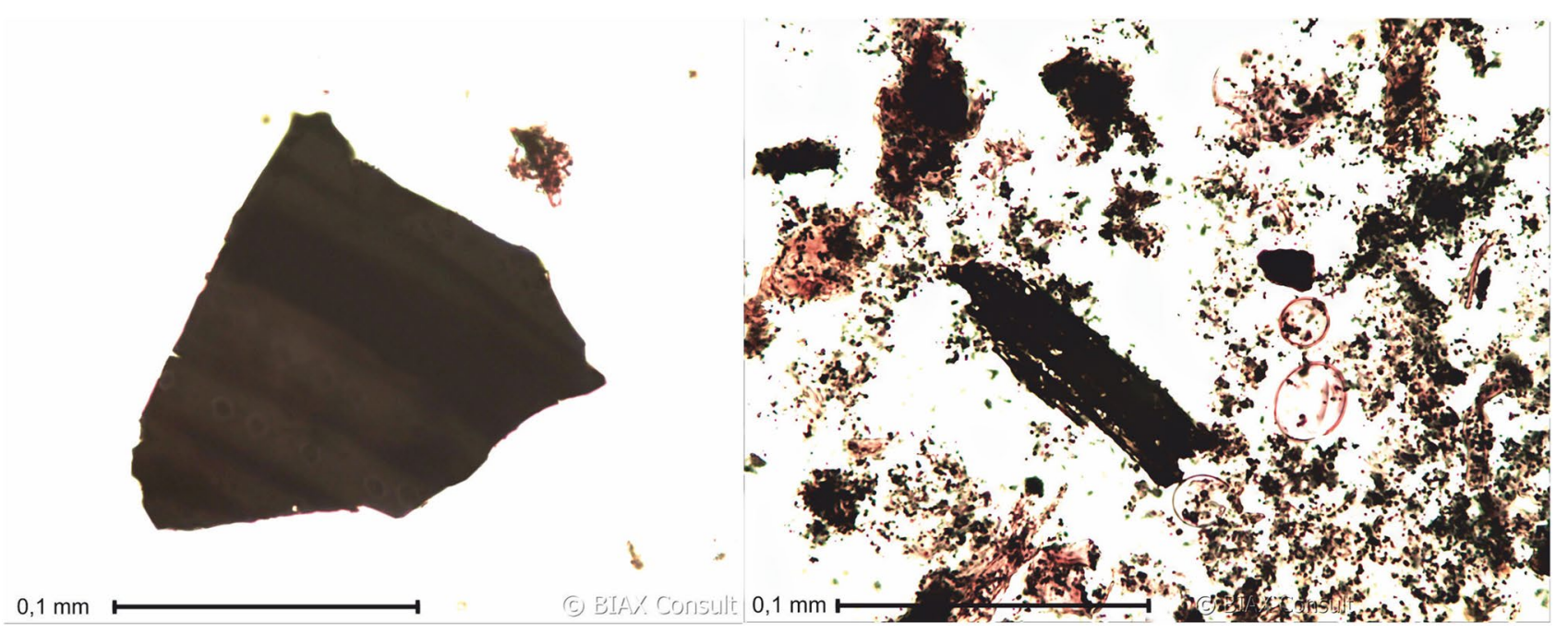

Fig. 10 Lubrza LU 18B charcoal particles; left, $138 \mu \mathrm{m}$ particle in the sample from $7.62 \mathrm{~cm}$ featuring bordered pits characteristic of coniferous wood; right, $100 \mu \mathrm{m}$ particle in the sample from $7.56 \mathrm{~cm}$, both correlated with the Bølling

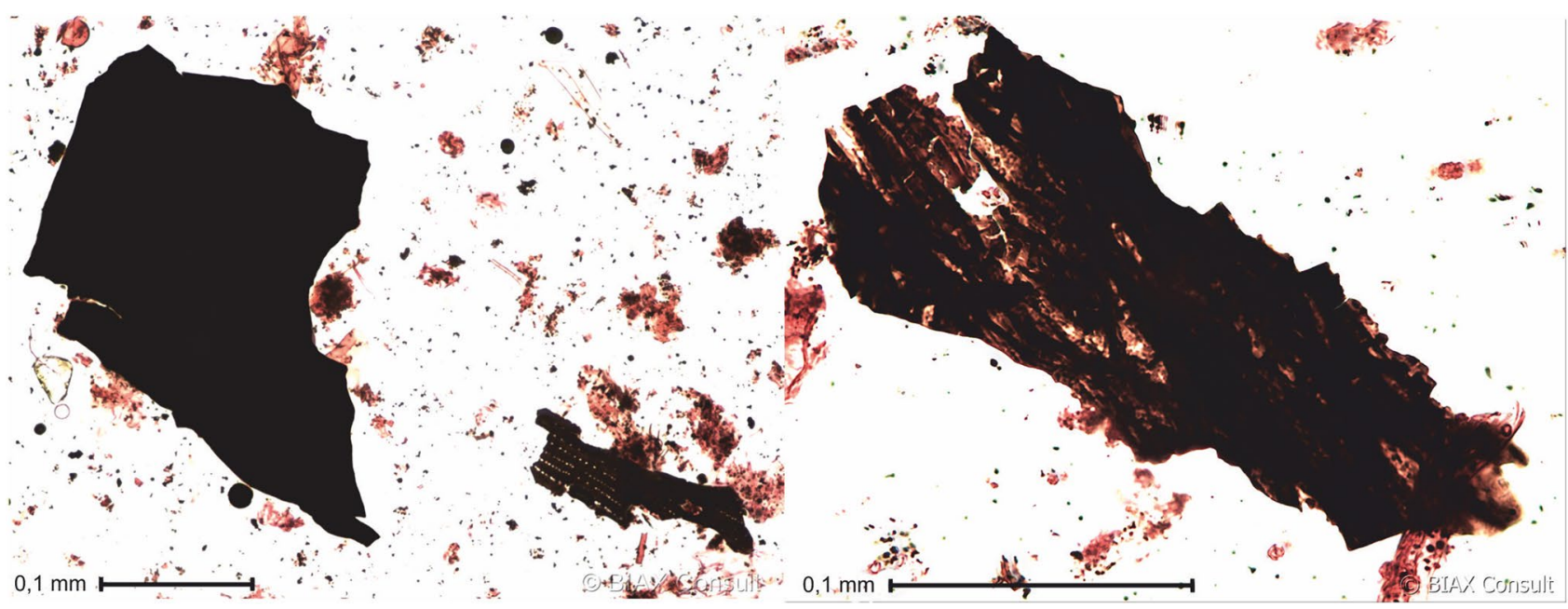

Fig. 11 Lubrza LU 18B charcoal particles; left, the largest fragment $(295 \mu \mathrm{m})$; right, charred herbaceous tissue (235 $\mu \mathrm{m})$ in the sample from $7.16 \mathrm{~cm}$, all showing the characteristic sharply broken edges, both correlated with the Allerød 
size classes (50-100 $\mu \mathrm{m}, 100-178 \mu \mathrm{m}$ and 200-390 $\mu \mathrm{m}$ ). Particles between $100 \mu \mathrm{m}$ and $178 \mu \mathrm{m}$ dominated the assemblages, while particles measuring $<100 \mu \mathrm{m}$ and $>200 \mu \mathrm{m}$ were found in smaller quantities.

The numbers of particles on each pollen slide were counted. The quantities of charred particles per analysed pollen slide varied from several (ca. 10, marked as + ) to numerous (up to ca. 100, marked as ++ ). The accumulation of charcoal particles is low but generally steady throughout much of the studied sequence. The highest numbers of charred particles $(++)$ were noted in the samples from between 750 and $758 \mathrm{~cm}$ within the palynologically defined Bølling oscillation (LPAZ II) and in the samples between 716 and $725 \mathrm{~cm}$, within the palynologically defined Allerød phase (LPAZ IV). In the sample from $716 \mathrm{~cm}$, in addition to wood charcoal particles, charred herbaceous tissues (including charred moss leaves) were also observed. Charcoal particles are more sporadically present in the lower section of the pollen zone LPAZ II which corresponds with the start of the Bølling, but no charred particles were noted in LPAZ I which corresponds with the Oldest Dryas.

There is relatively little research on microscopic charcoal particles and their association with human fire events from the Late Glacial sediment sequences in north-western and north-central Europe (Bos et al. 2013, 2017; Crombé et al. 2013; Sobkowiak-Tabaka et al. 2018; Krüger et al. 2020). Differentiating local from regional fires and establishing types of burnt vegetation in each fire are the essential steps to distinguish climate-related natural fire events from human fires (Olsson and Jonsson 2010). Most studies on the accumulation of charcoal particles indicate that the larger and heavier microscopic charcoal would have been deposited near the source of the fire. Their presence, therefore, is a clear indication of a local fire. Smaller and lighter particles, on the other hand, are transported over greater distances, and they therefore suggest regional fires (Clark et al. 1998; Blackford 2000; Carcaillet 2007; Olsson and Jonsson 2010). Blackford (2000) stated that charcoal particles smaller than $20 \mu \mathrm{m}$ are the most reliable indicators for regional 'background noise', while particles larger than $125 \mu \mathrm{m}$ would indicate a local fire. Tinner et al. (1998) and Duffin et al. (2008) recommended using charcoal particles greater than $50 \mu \mathrm{m}$ to reconstruct local fire history.

In Lubrza LU 18B, the dominant accumulation of charcoal particles in size classes between $100 \mu \mathrm{m}$ and $178 \mu \mathrm{m}$, accompanied occasionally by particles $>200 \mu \mathrm{m}$ and $>300 \mu \mathrm{m}$, may reflect local fires. The low total accumulation of charcoal particles further suggests that they were fires of low intensity as well as of a small scale. They were either natural fires or ones created by humans. It seems that the charred particles, reflected in the palynological record of LU 18B, most probably originated from human fires such as domestic (cooking) fires. Considering the proximity of the archaeological sites to the core location of Lubrza LU 18B, this assumption appears particularly justified. Lubrza site 37 , which contains archaeological remains associated with Hamburg groups, is some $200 \mathrm{~m}$ from the coring location. The find of a shouldered point, used as a projectile or a knife (Kufel-Diakowska 2019), offers direct evidence for human presence in the area during the Bølling period. Moreover, nearby, a large campsite of the Hamburg culture was discovered ca. $13 \mathrm{~km}$ to the east (Kabaciński and SobkowiakTabaka 2013). Therefore, the most likely explanation for the charcoal particle accumulations within the palynologically defined Bølling section of LU 18B (between 750 and $758 \mathrm{~cm}$ ) would be the presence of Hamburg groups in the area, possibly in various episodes.

Direct evidence for human occupation during the Allerød period was found at site 10 , located some $250 \mathrm{~m}$ from where core LU 18B was obtained. At this site, rich flint assemblages characteristic of the Federmesser tradition were found. The Federmesser groups, who frequented the area through much of the Allerød, would have been responsible for the accumulation of microcharcoal and charred particles of herbaceous plants at 695 to $734 \mathrm{~cm}$ in the core. The various activities of the Federmesser groups, such as the use of (domestic) fires and the burning of local (marsh) vegetation, were already indicated in the earlier study in the Lubrza area of LB 13, located some 500 m south of LU 18B (Fig. 1; Sobkowiak-Tabaka et al. 2018).

Additionally, in the period which can be linked to the presence of the Federmesser groups in the area, there was a relative increase in the frequency of Cladocera such as Coronatella rectangula, Chydonus sphaericus and Bosmida longirostris, as well as Disparalana rostrata, Monospilus dispar and Pleuroxus spp. which live in more eutrophic, turbid water (Pawłowski et al. 2013; Płóciennik et al. 2015). Such changes are correlated with high values of the $\mathrm{Na} / \mathrm{K}$ ratio (Figs. 6, 8). Although the concentration of elements from erosion ( $\mathrm{Na}, \mathrm{K}$ and $\mathrm{Mg}$ ) was relatively low (Fig. 8), a temporary high ratio of $\mathrm{Na} / \mathrm{K}$ could be an indicator of the relative changes in the weathering of aluminosilicates in sediments forming the substrate of the Lubrza catchment. Therefore, we assume that this situation displays a response of aquatic biota to the eutrophication caused by the gentle influx of nutrients and mineral matter to the lake (Kittel et al. 2014, 2021; Sobkowiak-Tabaka et al. 2020) and also by the presence of Federmesser groups and their deliberate burning of the marsh vegetation on the lake shore. The intense use of the Lubrza area continued during the Younger Dryas, when hunter-gatherers related to the Swiderian culture inhabited sites 10,11, 37 and 42. During this period, Swiderian groups interfered with the local environment by burning local marsh vegetation or sedge fen and using wood and herbaceous plants as raw materials (Sobkowiak-Tabaka et al. 2018; Sobkowiak-Tabaka and Kufel-Diakowska 2019). 
Based on the presence of microscopic charcoal in the Late Glacial palynological records from northwestern Belgium (Bos et al. 2013, 2017) and northern Germany (Krüger et al. 2020), these authors also suggested local fire episodes which may have been associated with various activities of the Late Palaeolithic groups in their studied areas. Bos et al. (2013) also proposed that charred remains of grass epidermis (probably Phragmites) would represent the burning of reed swamps, either as a result of natural fires or as active burning by Federmesser groups who frequented the area during the Allerød. Krüger et al. (2020) argued that charcoal particles recorded in pollen samples from the Nahe palaeolake correlated with the Younger Dryas may reflect human domestic fires, particularly when considering the closeness of the Late Palaeolithic Ahrensburg site to the coring location. At the same time, however, a combination of human and natural local fires cannot be ruled out completely.

\section{Conclusions}

The multi-proxy analyses in the last several years around Lubrza have yielded many data for the reconstruction of Late Glacial climatic and environmental changes. This study also showed that the Late Glacial palaeolakes at Lubrza are valuable archives of human activities in the area. This history of local vegetation began in the Oldest Dryas with subarctic tundra vegetation of dwarf shrubs, followed by the spread of Hippophaë rhamnoides in the area. Not long after, the first hunter-gatherers associated with the Hamburg culture appeared, and made their fires. During their occupation of the landscape, it was still rather open, with dwarf shrubs and scattered patches of Juniperus and H. rhamnoides shrubs. The first Betula trees then appeared in the landscape. During the early Allerød, tree birches expanded across the area, although the birch woods remained relatively open and allowed light-demanding vegetation to grow as well. During the later phase of the Allerød, a sparse pine woodland with birches and poplars developed, and belts of Salix (willow) grew along the lake shore. The diversity of marsh and water plants also increased through this period. The climate was now at its warmest point of the entire Late Glacial. Evidence for local human occupation by Federmesser culture groups and their various activities is well recorded in both the finds of stone tools and the archaeobotanical records; the use of campfires and the burning of local marsh vegetation are supported by microscopic charcoal and charred herbaceous plant particles deposited in palaeolakes 1 and 3 , located near the Federmesser sites. Human activities can also be recognised through Cladocera and geochemical records. During the colder Younger Dryas, the landscape changed significantly, in contrast to the previous warm Allerød period. The woodland was notably reduced and
Juniperus, Betula nana, Artemisia and Poaceae constituted a significant part of the local vegetation. The intense use of this area was also detected during the Younger Dryas, when hunter-gatherers associated with the Swiderian culture occupied various places in the area, now referred to as sites $10,11,37$ and 42 . Swiderian groups altered the local environment by burning local marsh vegetation and using wood and herbaceous plants as raw materials for construction and tools (Sobkowiak-Tabaka et al. 2018; Sobkowiak-Tabaka and Kufel-Diakowska 2019).

Overall, probably due to its favourable environmental conditions and rich geodiversity, which were good for camps, as well as hunting, fishing, plant gathering, crafting and obtaining firewood, the Lubrza area was repeatedly visited by various hunter-gatherer groups throughout much of the Late Glacial period.

Supplementary Information The online version contains supplementary material available at https://doi.org/10.1007/s00334-021-00863-w.

Acknowledgements This work was financed by the Narodowe Centrum Nauki (National Science Centre, Poland), grant 2016/21/B/HS3/03134, awarded to Iwona Sobkowiak-Tabaka. We are grateful to Przemysław Bobrowski and Paweł Wiktorowicz (Institute of Archaeology and Ethnology PAS) for their excellent help during the excavations, Bernadeta Kufel-Diakowska (Institute of Archaeology, Wrocław University) for sharing her unpublished data; Tomasz Karasiewicz (Mikołaj Kopernik University, Toruń) and Magdalena Ratajczak-Szczerba for taking the biogenic sediment cores, Małgorzata Suchorska for her laboratory work, and Joanna Delestowicz and Erika Ruhl for English editing. Last but not least we thank two anonymous reviewers for their valuable comments.

Funding Funding was provided by Narodowe Centrum Nauki (Grant Number 2016/21/B/HS3/03134).

Open Access This article is licensed under a Creative Commons Attribution 4.0 International License, which permits use, sharing, adaptation, distribution and reproduction in any medium or format, as long as you give appropriate credit to the original author(s) and the source, provide a link to the Creative Commons licence, and indicate if changes were made. The images or other third party material in this article are included in the article's Creative Commons licence, unless indicated otherwise in a credit line to the material. If material is not included in the article's Creative Commons licence and your intended use is not permitted by statutory regulation or exceeds the permitted use, you will need to obtain permission directly from the copyright holder. To view a copy of this licence, visit http://creativecommons.org/licenses/by/4.0/.

\section{References}

Alexandrowicz SW (1987) Analiza malakologiczna w badaniach osadów czwartorzędowych. Geologia 12. Wydawnictwo AGH, Kraków

Alexandrowicz WP (2007) Malakofauna późnoglacjalnych i holoceńskich węglanowych osadów jeziornych północnej Polski. Geologia 33:395-420 
Alexandrowicz SW, Alexandrowicz WP (2011) Analiza malakologiczna metody badań i interpretacji. (Malacological analyses methods of investigation and interpretation). Polska Akademia Umiejętności, Rozprawy Wydziału Przyrodniczego 3:5-302

Apolinarska K, Hammarlund D (2009) Multi-component stable isotope records from Late Weichselian and early Holocene lake sediments at Imiołki, Poland: palaeoclimatic and methodological implications. J Quat Sci 24:948-959

Baales M (1996) Umwelt und Jagdökonomie der Ahrensburger Rentierjäger im Mittelgebirge. Habelt, Bonn

Baales M (1999) Economy and seasonality in the Ahrensburgian. In: Kozłowski SK, Gurba J, Zalizniak L (eds) Tanged Point Cultures in Europe. Read at the International Archaeological Symposium Lublin, September 13-16, 1993. Lubelskie Materiały Archeologiczne 13. Maria Curie-Skłodowska University Press, Lublin, pp 64-75

Bąk M, Witkowski A, Żelazna-Wieczorek J, Wojtal AZ, Szczepocka E, Szulc K, Szulc B (2012) Klucz do oznaczania okrzemek w fitobentosie na potrzeby oceny stanu ekologicznego wód powierzchniowych w Polsce. Biblioteka Monitoringu Środowiska, Warszawa

Battarbee RW (1986) Diatom analysis. In: Berglund BE, Ralska-Jasiewiczowa M (eds) Handbook of holocene palaeoecology and palaeohydrology. Wiley, Chichester, pp 527-570

Beijerinck W (1947) Zadenatlas der Nederlandsche Flora. Wageningen, Veenman

Berggren G (1969) Atlas of seeds and small fruits of northwest European plant species (Sweden, Norway, Denmark, east Fennoscandia and Iceland) with morphological descriptions, Part 2: Cyperaceae. Swedish Natural Science Research Council, Stockholm

Berggren G (1981) Atlas of seeds and small fruits of northwest European plant species (Sweden, Norway, Denmark, east Fennoscandia and Iceland) with morphological descriptions, Part 3: Salicaceae - Cruciferae. Swedish Natural Science Research Council, Stockholm

Berglund BE, Ralska-Jasiewiczowa M (1986) Pollen analysis and pollen diagrams. In: Berglund BE, Ralska-Jasiewiczowa M (eds) Handbook of Holocene palaeoecology and palaeohydrology. Wiley, Chichester, pp 455-484

Beug H-J (2004) Leitfaden der Pollenbestimmung: für Mitteleuropa und angrenzende Gebiete. Fischer, Stuttgart, pp 30-42

Binford LR (1991) When the going gets tough, the tough get going: Nunamiut local groups, camping patterns, and economic organization. In: Ethnoarchaeological approaches to mobile campsites: hunter-gatherer and pastoralist case studies. (International Monographs in Prehistory, ethnoarchaeology series 1, (ed) Boismier WA, Gamble CS. University of Michigan, Ann Arbor, Michigan, pp 25-137

Bjerring R, Becares E, Declerck S et al (2009) Subfossil Cladocera in relation to contemporary environmental variables in 54 PanEuropean lakes. Freshw Biol 54:2401-2417

Blackford JJ (2000) Charcoal fragments in surface samples following a fire and the implications for interpretation of subfossil charcoal data. Palaeogeogr Palaeoclimatol Palaeoecol 164:33-42

Błaszkiewicz M (2007) Geneza i ewolucja mis jeziornych na młodoglacjalnym obszarze Polski - wybrane problemy. Stud Lim Et Tel 1:5-16

Błędzki LA, Rybak JI (2016) Freshwater Crustacean Zooplankton of Europe. Cladocera \& Copepoda (Calanoida, Cyclopoida). Key to species identification, with notes on ecology, distribution, methods and introduction to data analysis. Springer, Cham

Bos JAA, Verbruggen F, Engels S, Crombe P (2013) The influence of environmental changes on local and regional vegetation patterns at Rieme (NW Belgium): implications for Final Palaeolithic habitation. Veget Hist Archaeobot 22:17-38
Bos JAA, De Smedt P, Demiddele H et al (2017) Multiple oscillations during the Lateglacial as recorded in a multi-proxy, highresolution record of the Moervaart palaeolake (NW Belgium). Quat Sci Rev 162:26-41

Bronk Ramsey C (2009) Dealing with outliers and offsets in radiocarbon dating. Radiocarbon 51:1023-1045. https://doi.org/10.1017/ S0033822200034093

Cappers RTJ, Bekker RM, Jans JEA (2006) Digital seed atlas of the Netherlands. Barkhuis Publishing, Eelde

Carcaillet C (2007) Palaeobotany: Charred particle analysis. In: Elias SA (ed) Encyclopedia of quaternary science. Elsevier, Amsterdam, pp 1582-1593

Chmal R (2003) Objaśnienia do Szczegółowej Mapy Geologicznej Polski, Arkusz Toporów (501). Państwowy Instytut Geologiczny, Warszawa

Clark JS, Lynch J, Stocks BJ, Goldammer JG (1998) Relationships between charcoal particles in air and sediments in west-central Siberia. Holocene 8:19-29

Crombé P, De Smedt P, Davies NS et al (2013) Hunter-gatherer responses to the changing environment of the Moervaart palaeolake (NW Belgium) during the Late Glacial and Early Holocene. Quat Int 308-309:162-177

Cziesla E (2018) Seal-hunting in the final palaeolithic of Northern Europe. In: Persson P, Riede F, Skar B, Breivik HM, Jonsson L (eds) The ecology of early settlement in Northern Europe. Equinox Publishing, Sheffield, Conditions for subsistence and survival, pp 55-97

Diachenko A, Sobkowiak-Tabaka I (2020) Micro-chronology of Palaeolithic open-air sites: the model. J Archaeol Sci 117:115125

Duffin KI, Gillson L, Willis KJ (2008) Testing the sensitivity of charcoal as an indicator of fire events in savanna environments: quantitative predictions of fire proximity, area and intensity. Holocene 18:279-291

Ellenberg H, Weber HE, Düll R et al (1991) Zeigerwerte von Pflanzen in Mitteleuropa. (Scripta Geobotanica 18) Goltze, Göttingen

Faustova M, Sacherová V, Svensson J-E, Taylor DJ (2011) Radiation of European Eubosmina (Cladocera) from Bosmina (E.) longispina-concordance of multipopulation molecular data with paleolimnology. Limnol Oceanogr 56:440-450

Fiebig J, Schöne BR, Oschmann W (2005) High-precision oxygen and carbon isotope analysis of very small $(10-30 \mu \mathrm{g})$ amounts of carbonates using continuous flow isotope ratio mass spectrometry. Rapid Commun Mass Spectrom 19:2355-2358

Flössner D (1972) Die Tierwelt Deutschlands und der angrenzenden Meeresteile nach ihren Merkmalen und nach ihrer Lebensweise T. 60: Krebstiere, Crustacea (Kiemen- und Blattfüßer, Branchiopoda, Fischläuse, Branchiura). Fischer, Jena

Flössner D (2000) Die Haplopoda und Cladocera (ohne Bosminidae) Mitteleuropas. Backhuys Publishers, Leiden

Frey DG (1986) Cladocera analysis. In: Berglund BE, Ralska-Jasiewiczowa M (eds) Handbook of holocene palaeoecology and palaeohydrology. Wiley, Chichester, pp 667-692

Gittenberger E, Janssen AW, Kuijper WJ et al (2004) De Nederlandse zoetwatermollusken: recente en fossiele weekdieren uit zoet en brak water. Nederlandse Fauna 2. Nationaal Natuurhistorisch Museum Naturalis, Leiden

Gordon BC (1988) Of men and reindeer herds in French Magdalenian Prehistory. (BAR International Series 390) BAR Publishing, Oxford

Goslar T, van der Knaap WO, Kamenik C, van Leeuwen JFN (2009) Free-shape ${ }^{14} \mathrm{C}$ age-depth modelling of an intensively dated modern peat profile. J Q Sci 24:481-499. https://doi.org/10.1002/ jqs. 1283

Grimm EC (1992) Tilia and Tilia-Graph. Pollen Spreadsheet and Graphics Programs. 8th International Palynological Congress, 
Aix-en-Provence, September 6-12, 1992. Program and Abstracts 56

Heiri O, Lotter AF, Lemcke G (2001) Loss on ignition as a method for estimating organic and carbonate content in sediments: reproducibility and comparability of results. J Paleolimnol 25:101-110. https://doi.org/10.1023/A:1008119611481

Hitchcock CL, Cronquist A, Ownbey M, Thompson JW (1969) Vascular plants of the Pacific Northwest, Part 1: vascular cryptograms, gymnosperms, and monocotyledons. (University of Washington Publications in Biology 17) University of Washington Press, Seattle

Hoek WZ, Bohncke SJP, Ganssen GM, Meijer T (1999) Lateglacial environmental changes recorded in calcareous gyttja deposits at Gulickshof, southern Netherlands. Boreas 28:416-432

Hošek J, Pokorný P, Kubovčík V et al (2014) Late glacial climatic and environmental changes in eastern-central Europe: correlation of multiple biotic and abiotic proxies from the Lake Švarcenberk, Czech Republic. Palaeogeogr Palaeoclimatol Palaeoecol 396:155-172. https://doi.org/10.1016/j.palaeo. 2013.12.024

Huntley B, Birks HJB (1983) An atlas of past and present pollen maps for Europe: 0-13000 years ago. Cambridge University Press, Cambridge

Hustedt F (1939) Die Diatomeenflora des Küstengebietes der Nordsee vom Dollart bis zur Elbmündung. Abh Naturwiss Ver Bremen 31:571-677

Iversen J (1954) The Late-Glacial flora of Denmark and its relation to climate and soil. Danm Geol Unders, 2 Række, 80:87-119

Jasiewicz J, Sobkowiak-Tabaka I (2015) Geo-spatial modelling with unbalanced data: modelling the spatial pattern of human activity during the Stone Age. Open Geosci 7:289-307

Jones RL, Keen DH (1993) The Flandrian temperate stage. In: Jones RL, Keen DH (eds) Pleistocene environments in the British Isles. Springer, Dordrecht, pp 208-274

Juggins S (2017) Rioja: analysis of Quaternary science data, R package version (0.9-15). http://cran.r-project.org/packa ge=rioja

Kabaciński J, Sobkowiak-Tabaka I (2010) Between East and Westa new site of the Federmessergruppen in Poland. Quartär 57:139-154

Kabaciński J, Sobkowiak-Tabaka I (2011) Schyłkowy paleolit. In Kabaciński J, Sobkowiak-Tabaka I (eds) Materiały do wczesnych pradziejów Zachodniej Wielkopolski. Osadnictwo pradziejowe i wczesnośredniowieczne w Lubrzy. Ratownicze badania archeologiczne Instytutu Archeologii i Etnologii PAN, Oddział w Poznaniu. Instytut Archeologii i Etnologii PAN, Poznań, pp 195-262

Kabaciński J, Sobkowiak-Tabaka I (2013) Osadnictwo społeczności kultury hamburskiej na Pojezierzu Lubuskim. Wydawnictwo Instytutu Archeologii i Etnologii PAN, Poznań

Karasiewicz TM (2019) The kettle-hole mire as archives of postglacial changes in biogenic sedimentation (Tuchola Forest, northCentral Poland). CATENA 176:26-44

Kittel P, Muzolf B, Płóciennik M et al (2014) A multi-proxy reconstruction from Lutomiersk-Koziówki, Central Poland, in the context of early modern hemp and flax processing. J Archaeol Sci 50:318-337. https://doi.org/10.1016/j.jas.2014.07.008

Kittel P, Mazurkevich A, Więckowska-Lüth M et al (2021) On the border between land and water: the environmental conditions of the Neolithic occupation from 4.3 until $1.6 \mathrm{ka} \mathrm{BC}$ at Serteya. Western Russia Geoarchaeology 36:173-202. https://doi.org/10. 1002/gea.21824

Kobusiewicz M (1999) Ludy łowiecko-zbierackie północno-zachodniej Polski. Poznańskie Towarzystwo Przyjaciół Nauk, Poznań

Kolkwitz R, Marrson M (1908) Ökologie der pflanzlichen Saprobien. Ber Dtsch Bot Ges 26a:505-519
Komárek J, Jankovská V (2001) Review of the green algal genus Pediastrum; implication for pollen-analytical research. (Bibliotheca Phycologica 108) J. Cramer, Berlin

Krüger S, Damrath M (2020) In search of the Bølling-Oscillation: a new high resolution pollen record from the locus classicus Lake Bølling, Denmark. Veget Hist Archeobot 29:189-211. https:// doi.org/10.1007/s00334-019-00736-3

Krüger S, Fischer Mortensen M, Dörfler W (2020) Sequence completed-palynological investigations on Late Glacial/Early Holocene environmental changes recorded in sequentially laminated lacustrine sediments of the Nahe palaeolake in Schleswig-Holstein. Germany. Rev Palaeobot Palynol 280:104271

Kubiak-Martens L (2016) Local vegetation and human presence in the Wojnowo Region during the Younger Dryas and Early Holocene. In: Kobusiewicz M (ed) Region Wojnowo. Arkadia łowców i zbieraczy. Ośrodek Studiów Pradziejowych i Średniowiecznych Instytut, Archeologii i Etnologii Polskiej Akademii Nauk, Poznań, pp 59-74. http://www.iaepan.poznan.pl/iaepa n01/ image s/PDF/Region-Wojnowo.-Arkad ia-owcw-i-zbieraczy-2a. pdf. Accessed 5 December 2016

Kufel-Diakowska B (2019) Raport z badań traseologicznych artefaktów kamiennych odkrytych na stanowisku nr 37 w Lubrzy (Manuscript)

Lang G (1994) Quartäre Vegetationsgeschichte Europas: Methoden und Ergebnisse. Fischer, Jena

Ložek V (1964) Quartärmollusken der Tschechoslowakei. (Rozpravy Ústředního ústavu geologického 31) Verlag der Tschechoslowakischen Akademie der Wissenschaften, Praha

Miall AD (1985) Architectural-element analysis: a new method of facies analysis applied to fluvial deposits. Earth-Sci Rev 22:261-308

Mirosław-Grabowska J, Obremska M, Zawisza E, Radzikowska M, Stańczak J (2020) Towards a dystrophic lake: the history of Smolak Lake (northern Poland) on the basis of geochemical and biological data. Catena 187:104262

Naumann E (1932) Grundzüge der regionalen Limnologie, vol 11. Schweizerbartsche Verlagsbuchhandlung, Stuttgart, Die Binnengewässer

Olsson J, Jonsson BG (2010) Restoration fire and wood-inhabiting fungi in a Swedish Pinus sylvestris forest. For Ecol Manag 259:1971-1980

Pawłowski D (2012) Younger Dryas Cladocera assemblages from two valley mires in central Poland and their potential significance for climate reconstructions. Geologos 18:237-249. https://doi.org/ 10.2478/v10118-012-0012-2

Pawłowski D, Gruszka B, Gallas H, Petera-Zganiacz J (2013) Changes in the biota and sediments of glacial Lake Koźmin, Poland, during the late Saalian (Illinoian). J Paleolimnol 49:679-696. https:// doi.org/10.1007/s10933-013-9692-z

Piechocki A, Wawrzyniak-Wydrowska B (2016) Guide to freshwater and marine mollusca of Poland. Bogucki Wydawnictwo Naukowe, Poznań

Płóciennik M, Kruk A, Forysiak J et al (2015) Fen ecosystem responses to water-level fluctuations during the early and middle Holocene in central Europe: a case study from Wilczków, Poland. Boreas 44:721-740. https://doi.org/10.1111/bor.12129

Ratajczak-Szczerba M (2014) Sytuacja geologiczna paleozbiornika stanowiska 10 i 11 w Lubrzy - sezon 2014 i podsumowanie całości badań (Manuscript)

Ratajczak-Szczerba M, Sobkowiak-Tabaka I, Okuniewska-Nowaczyk I (2015) Palaeogeographical and archaeological records of natural changes of the Jordanowo-Niesulice subglacial channel near Lubrza, the Lubusz Lakeland. Quaest Geogr 34:101-116

Reimer PJ, Austin WEN, Bard E et al (2020) The IntCal20 Northern Hemisphere radiocarbon age calibration curve $(0-55$ cal ka BP). Radiocarbon 62:725-757. https://doi.org/10.1017/RDC.2020.41 
Round FE (1981) The ecology of Algae. Cambridge University Press, Cambridge

Sarmaja-Korjonen K (2003) Chydorid ephippia as indicators of environmental change-biostratigraphical evidence from two lakes in southern Finland. Holocene 13:691-700

Schlanger SH (1992) Recognizing persistent places in Anasazi settlement systems. In: Rossignol J, Wandsnider L (eds) Space, time and archaeological landscapes. Plenum Press, New York, pp 91-112

Schrader H-J, Gersonde R (1978) Diatoms and Silicoflagellates. Utrecht Micropaleontol Bull 17:129-176

Schwander J, Eicher U, Ammann B (2000) Oxygen isotopes of lake marl at Gerzensee and Leysin (Switzerland), covering the Younger Dryas and two minor oscillations, and their correlation to the GRIP ice core. Palaeogeogr Palaeoclimatol Palaeoecol 159:203-214

Schweingruber FH (1990) Mikroskopische Holzanatomie: Formenspektren mitteleuropäischer Stamm- und Zweighölzer zur Bestimmung von rezentem und subfossilem Material. Eidgenössische Forschungsanstalt für Wald, Schnee und Landschaft, Birmensdorf

Słowiński M, Zawiska I, Ott F et al (2017) Differential proxy responses to late Allerød and early Younger Dryas climatic change recorded in varved sediments of the Trzechowskie palaeolake in Northern Poland. Q Sci Rev 158:94-106

Sobkowiak-Tabaka I (2016) The last Late Glacial hunter-gatherers. In: Kabaciński J, Urbańczyk P (eds) The Past Societies. Polish lands from the first evidence of human presence to the Early Middle Ages, vol 1, 500000-5500 BC. Instytut Archeologii i Etnologii Polskiej Akademii Nauk, Warszawa, pp 199-227

Sobkowiak-Tabaka I (2017) Rozwój społeczności Federmesser na Nizinie Środkowoeuropejskiej. Instytut Archeologii i Etnologii Polskiej Akademii Nauk, Warszawa

Sobkowiak-Tabaka I, Diachenko A (2020) Approaching daily life at Late Palaeolithic camps: the case of Lubrza 10, Western Poland. Praehist Z 92:311-333. https://doi.org/10.1515/pz-2020-0031

Sobkowiak-Tabaka I, Kufel-Diakowska B (2019) The shining piece of puzzle: evidence of plant use in the Late Palaeolithic. Archaeol Anthropol Sci 11:1373-1389. https://doi.org/10.1007/ s12520-018-0604-z

Sobkowiak-Tabaka I, Kubiak-Martens L, Okuniewska-Nowaczyk I et al (2018) Reconstruction of the Late Glacial and Early Holocene landscape and human presence in Lubrza, Western Poland, on the basis of multidisciplinary analyses. Environ Archaeol 23:123136. https://doi.org/10.1080/14614103.2016.1268993

Sobkowiak-Tabaka I, Pawłowski D, Milecka K et al (2020) Multi-proxy records of Mesolithic activity in the Lubuskie Lakeland (western Poland). Veget Hist Archaeobot 29:153-171. https://doi.org/10. 1007/s00334-019-00752-3

Spötl C, Vennemann TW (2003) Continuous-flow isotope ratio mass spectrometric analysis of carbonate minerals. Rapid Commun Mass Spectrom 17:1004-1006
Szeroczyńska K, Sarmaja-Korjonen K (2007) Atlas of subfossil Cladocera from Central and Northern Europe. Friends of Lower Vistula Society, Świecie

Tinner W, Conedera M, Ammann B, Gaggeler HW, Gedye S, Jones R, Sagesser B (1998) Pollen and charcoal in lake sediments compared with historically documented forest fires in southern Switzerland since AD 1920. Holocene 8:31-42

Turner F, Tolksdorf JF, Viehberg F et al (2013) Lateglacial/early Holocene fluvial reactions of the Jeetzel river (Elbe valley, northern Germany) to abrupt climatic and environmental changes. Q Sci Rev 60:91-109. https://doi.org/10.1016/j.quascirev.2012.10.037

Usinger H (1985) Pollenstratigraphische, vegetations- und klimageschichtliche Gliederung des "Bölling-Alleröd-Komplexes" in Schleswig-Holstein und die Bedeutung für die SpätglazialStratigraphie in benachbarten Gebieten. Flora 177:1-43

Van Damme K, Dumont HJ (2008) Further division of Alona Baird, 1843: separation and position of Coronatella Dybowski \& Grochowski and Ovalona gen.n. (Crustacea: Cladocera). Zootaxa 1960:1-44

Van Damme K, Kotov AA, Dumont HJ (2010) A checklist of names in Alona Baird, 1843 (Crustacea: Cladocera: Chydoridae) and their current status: an analysis of the taxonomy of a lump genus. Zootaxa 2330:1-63

Vanmontfort B, Van Gils M, Paulissen E et al (2010) Human occupation of the Late and Early Post-Glacial environments in the Liereman Landscape (Campine, Belgium). J Archaeol Low Countries 2:31-51

Wasylikowa K (1964) Roślinność i klimat późnego glacjału w środkowej Polsce na podstawie badań w Witowie koło Łęczycy (Vegetation and climate of the Late-Glacial in central Poland based on investigations made at Witów near Łęczyca). Biul Peryglac 13:261-417

Whiteside MC (1970) Danish Chydorid Cladocera: modern ecology and core studies. Ecol Monogr 40:79-118

Zieliński T (1995) Kod litofacjalny i litogenetyczny - konstrukcja i zastosowanie. In: Mycielska-Dowgiałło E, Rutkowski J (eds) Badania osadów czwartorzędowych: wybrane metody i interpretacja. Wydział Geografii i Studiów Regionalnych Uniwersytetu Warszawskiego, Warszawa, pp 220-235

Żynda S (1967) Geomorfologia przedpola moreny czołowej stadiału poznańskiego na obszarze wysoczyzny lubuskiej. (Prace Komisji Geograficzno-Geologicznej - Poznańskie Towarzystwo Przyjaciół Nauk 8, 1) Państwowe Wydaw. Naukowe - Oddział w Poznaniu, Poznań

Publisher's Note Springer Nature remains neutral with regard to jurisdictional claims in published maps and institutional affiliations. 